\title{
3. RADY OSIEDLOWE JAKO CZYNNIK ZMIENIAJĄCY DYSPROPORCJE W PRZESTRZENI MIASTA NA PRZYKŁADZIE ŁODZI
}

\subsection{Problem, cel badań, przedmiot i materiały źródłowe}

Pojęcie dysproporcji (nierówności) jest wieloznaczne i wielowymiarowe, ma w sobie wiele sprzeczności a przez to jest nieostre i ambiwalentne w ocenie. Samo zjawisko wpisane jest w kulturę i strukturę społeczną, co powodują różną jego interpretacje; w kategoriach aksjologicznych jest przeciwieństwem równości, zaprzeczeniem postulatu etycznego, w wymiarze podmiotowym określa naszą indywidualność i potencjał, który $\mathrm{w}$ nas drzemie, $\mathrm{w}$ wymiarze społecznym jest przyczyną nieporozumień i konfliktów i wyznacznikiem ludzkich relacji, w wymiarze ekonomicznym jest natomiast motorem rozwoju i wskazuje na istnienie gospodarczych szans (Zubik, Cieślik, 2007).

Dysproporcje przestrzeni rzeczywistej (realnej), czyli brak proporcji między przedmiotami, ich cechami lub zjawiskami niezależnie od tego, czy odnosimy je do wymiarów fizycznych (przestrzeni autotelicznej) czy niefizycznych (przestrzeni heterotelicznej) (Chojnicki 1999; Lisowski 2003), stanowią efekt działania teraz i w przeszłości różnych czynników sprawczych, których wszystkich nie sposób tutaj wymienić. Najogólniej można stwierdzić, że mają one z jednej strony charakter przyrodniczy $\mathrm{z}$ drugiej antropogeniczny, w tym historyczny. W odniesieniu do przestrzeni miejskiej czynniki z tej drugiej grupy odgrywają rolę decydującą, wpływają na nierówności zagospodarowania przestrzeni fizycznej oraz kształtują nierówności społeczno-przestrzenne. W wymiarze drugim z pojęciem nierówności kojarzą się takie terminy, jak: „wykluczenie”, „marginalizacja”, „dyskryminacja”, „uprzedzenia”, które mają także swój aspekt przestrzenny, kojarząc się jednoznacznie z miejscami w przestrzeni fizycznej zaniedbanymi, zdekapitalizowanymi o złym zagospodarowaniu.

Niezależnie od tego o jakich wymiarach nierówności mówimy i jakie są ich czynniki sprawcze, nierówności te wpływają w sposób dynamizujący na każde społeczeństwo przyczyniając się równocześnie do jego integracji i dezintegracji w zależności od czasu i miejsca. 
W miastach, egzemplifikacją samorządności pomocniczej są rady osiedlowe, których działania mogą być jednym z czynników wpływających na kształtowanie się różnic, przede wszystkim w zagospodarowaniu ich przestrzeni. Rady Osiedlowe są tworami społecznymi wybieranymi w sposób demokratyczny w wyborach bezpośrednich. Są one instytucjonalnie związane z działaniami samorządu gminnego, który deleguje pewne funkcje na swoje jednostki pomocnicze, tj. wydzielone jednostki przestrzenne (osiedla). 0 możliwości ich utworzenia decyduje rada miasta w statucie miasta, który określa również ustrój wewnętrzny poszczególnych osiedli, uszczegółowiony w statutach własnych jednostek pomocniczych. Rada miasta tworząc taką jednostkę określa jej zadania i kompetencje oraz oddaje do dyspozycji majątek. Nie oznacza to jednak, że jednostki pomocnicze na terenie jednego miasta mają tożsame zadania i kompetencje (Słownik podstawowych terminów samorządu terytorialnego 2007).

Działalność rad osiedlowych staje się więc jednym z czynników społeczno-politycznych wpływających na modernizację zagospodarowania przestrzeni osiedli i organizację w nich życia społecznego. Od charakteru tej działalność (sprawności, intensywności i zaangażowania) oraz zdolności pobudzania mobilizacji społeczności lokalnych zależą zmiany, jakie zachodzą w osiedlach, co w konsekwencji wpływa, obok innych przyczyn, na różnicowanie się przestrzeni realnej miasta.

W przeprowadzonych badaniach jednostka pomocnicza miasta jest rozumiana w kategorii administracyjnej społeczności terytorialnej (osiedle), która jest zarazem wspólnotą samorządową. Z jednostką pomocniczą wiąże się ściśle pojęcie rady osiedla, która jest organem uchwałodawczym samorządu osiedlowego i powołuje zarząd jako organ wykonawczy. Zdaniem Turowskiego (1979) w osiedlu, bez względu na jego konotacje przedmiotowe, powstaje możliwość budowy samorządu, dzięki któremu możliwe jest wytworzenie wspólnoty lokalnej.

Badania rad osiedlowych wydają się istotne nie tylko z tego powodu, że wpływają one na zmianę jakości fizycznej przestrzeni osiedlowych, ale także z tego powodu, że są także wyrazem integracji i mobilizacji społeczności lokalnych w kierunku kształtowania własnej przestrzeni ekologicznej, własnego miejsca życia. Szerokie omówienie dorobku teoretycznego w zakresie badania rad osiedlowych, oraz propozycję modelu ich działania i jego empiryczną weryfikację na przykładach Poznania i Kalisza, zawiera książka Piotra Matczaka pt. Rady osiedli: w poszukiwaniu sensu lokalnego działania (2008).

Celem ogólnym przeprowadzonych badań była weryfikacja postawionej hipotezy o roli i znaczeniu rad osiedlowych jako czynnika konstruowania i kształtowania nierówności w przestrzeni realnej Łodzi, w jej wymiarach fizycznych oraz i społeczno-przestrzennych. Ideologiczną istotą 
funkcjonowania rad osiedlowych jest kreowanie rozwoju i tym samym wyrównywanie dysproporcji pomiędzy różnymi przestrzeniami miasta. Jednak działalność poszczególnych rad osiedlowych, których efektem są zmieniające się dysproporcje przestrzenne w mieście, sama jest odmienna, co wynika z szeregu czynników sprawczych, które mają charakter zewnętrzny (egzogenny) i wewnętrzny (endogenny). Pierwszą grupę tworzą czynniki prawno-ekonomiczne, drugą natomiast uwarunkowania przestrzenne i społeczne. Dlatego też, by opisać mechanizmy kreowania zmian przestrzeni miejskiej przez najniższy szczebel samorządu terytorialnego, trzeba wniknąć i zrozumieć czynniki stymulujące oraz ograniczające jego działalności.

Osiągnięcie celu badań sprowadza się do sformułowania i opisania kilku podstawowych problemów:

- Podstaw prawno-ekonomicznych funkcjonowania rad osiedlowych, które określają ich możliwości funkcjonowania, czyli realne kompetencje. Działania rad - formy i sposoby - w założeniach powinny realizować zasady samorządności mieszkańców, takie jak wspólnotowość, solidarność, lokalność i autonomiczność. Rady osiedlowe działają na mocy istniejącego ogólnego prawa odnoszącego się do samorządów terytorialnych oraz prawa o charakterze lokalnym stanowionego przez terenowe organa administracji samorządowej, w tym przypadku gminy miejskiej Łódź. Sensy ich działania polegają na samodzielności zarządzania, a także na istnieniu woli zbiorowej i rządzących, którzy działają w publicznym interesie grupy. Od miejsca rad osiedlowych w systemie obowiązującego prawa, zwłaszcza lokalnego, zależy ich siła oddziaływania na przestrzeń fizyczną i społeczną jednostek terytorialnych (osiedli).

- Podziału przestrzeni miasta na jednostki pomocnicze samorządu terytorialnego (nazywane osiedlami) ich genezy, położenia, charakteru zagospodarowania i dominujących funkcji w strukturze przestrzennej Łodzi.

- Sposobu wyłaniania członków rad osiedlowych ich cech społecznych, organizacyjnych form pracy wykonywanej tudzież relacji z władzami miasta i mieszkańcami osiedli.

- Obszarów, w których rady działają i zmieniają fizyczną przestrzeń osiedli, przyczyniając się do lepszego zaspokajania potrzeb mieszkańców.

- Świadomości społecznej mieszkańców miasta, odnośnie do potrzeby istnienia jednostek pomocniczych samorządu terytorialnego, ich zadań i możliwości działań, a także społecznej akceptacji roli w kształtowaniu warunków miejsca życia i budowaniu społeczności lokalnej.

Przedmiotem badań były rady osiedlowe w Łodzi, traktowane jako czynnik zmian oraz identyfikowane poprzez ich organizację, działanie, 
skład osobowy, a także mieszkańcy osiedli, w zakresie utrzymywanych relacji i postrzegania rad osiedli. Na terenie miasta działa 36 takich jednostek, ukonstytuowanych w wyniku ważnych wyborów do organu uchwałodawczego osiedla, którym jest rada osiedla. Oglądowi poddano przestrzeń działania rad osiedlowych, którą oceniono z punktu widzenia możliwości realizacji zasad samorządności. Samorządność można tutaj podzielić na funkcjonalną, która odzwierciedla organizację i zarządzanie oraz organiczną, którą charakteryzują działania spontaniczne, i która opiera się na wspólnotowości, solidarności, lokalności i autonomiczności.

Badaniami szczegółowymi objęto łącznie 19 jednostek osiedlowych, dla pięciu z nich (Radogoszcz, Śródmieście-Wschód, Chojny Dąbrowa, Stoki i Osiedle im. M. Mireckiego) wykorzystano badania wcześniejsze, z roku 2009, przeprowadzone $\mathrm{w}$ ramach pracy magisterskiej kierowanej przez autora tego opracowania (Weber 2010).

Wykorzystano szereg metod badawczych zarówno terenowych, jak i kameralnych. Podstawą były wywiady standaryzowane przeprowadzone na podstawie dwóch kwestionariuszy. Zaletą wywiadu jest anonimowość, możliwość uzyskania wielu informacji, ponadto bezpośredni kontakt z respondentami stwarza okazję do poznania ich poglądów, sposobu myślenia, stosunku do spraw i ludzi. Chociaż badania ankietowe zawsze budzą pewne wątpliwości, to jednak ich wiarygodność można opierać na dobrowolności udziału respondentów w badaniach.

Pierwszy rodzaj wywiadów miał za zadanie określić wizerunek rad osiedlowych w oczach mieszkańców wybranych do badań pięć osiedli. W okresie od lipca do październik 2009 r. przebadano łącznie 100 osób, przy czym na Radogoszczu - 30, na osiedlu Chojny-Dąbrowa - 30, im. Montwiłła Mireckiego - 10, Śródmieściu-Wschód - 20, i na Stokach - 10 (Weber 2010). Liczbę przeprowadzonych wywiadów, która była generalnie uzależniona od liczby mieszkańców osiedli, trudno uznać za reprezentatywną w znaczeniu statystycznym, stąd mają one charakter jedynie sondażowy. Badania pozwoliły również na pewną ocenę realizacji idei samorządności społecznej oraz jej urzeczywistnianie w życiu społecznym.

Drugi kwestionariusz przeznaczony był dla przewodniczących rad osiedlowych, z którymi przeprowadzono 14 wywiadów w lutym 2013 r. (z przewodniczącymi osiedli: Wiskitno, Julianów-Marysin-Rogi, Górniak, Chojny, Bałuty Zachodnie, Bałuty Doły, Bałuty Centrum, Osiedle 33, Karolew-Retkinia Wschód, Łagiewniki, Teofilów Wielkopolska, Radogoszcz, Ruda, Zdrowie-Mania). W sumie, w obu rodzajach badań ankietowych przebadano 19 osiedli łódzkich, z punktu widzenia funkcjonowania rad osiedlowych oraz ich percepcji przez mieszkańców. Wiedzę, którą pozyskano $\mathrm{w}$ trakcie tych wywiadów uzupełniono o informacje zawarte 
$\mathrm{w}$ rozmowach przeprowadzonych $\mathrm{z}$ przewodniczącymi rad na portalu internetowym „hallo tu Łódź” (http://www.halolodz.pl/).

Ważną metodą, która posłużyła do uzyskania wielu cennych informacji, była kwerenda w urzędach i instytucjach. Szczegółowe informacje na temat działania jednostek pomocniczych Łodzi otrzymano bezpośrednio w siedzibach badanych rad osiedli oraz w Oddziale ds. Jednostek Pomocniczych Miasta Wydziału Spraw Społecznych Urzędu Miasta Łodzi.

Cennym źródłem informacji były wiadomości zamieszczone na stronach internetowych Urzędu m. Łodzi poświęconych radom osiedlowym. Przeprowadzono również lustrację terenową, która dostarczyła wiele informacji na temat zagospodarowania i ładu przestrzennego osiedli. Skorzystano także z licznej literatury przedmiotu wprowadzającej w tematykę oraz z publikacji dokumentów, takich jak np. statuty czy ustawa. Wiele informacji można znaleźć w Ustawie o Samorzqdzie Gminnym z dnia 8 marca 1990 r. (DzU, 1990, 2005, nr 16, poz. 95), Statucie Miasta Łodzi z dnia 23 listopada 2005 r. (Dz Urz. Woj. Łódzkiego, 2005, nr 23, poz. 148) oraz statutach poszczególnych jednostek pomocniczych. Przedstawiają one w sposób szczegółowy zadania i kompetencje samorządu pomocniczego na terenie miasta, chociaż - jak wiadomo - żadne przepisy nie rozstrzygają kwestii efektywności ich działań. Istotne okazały się ponadto niektóre uchwały Rady Miejskiej w Łodzi, m.in. te dotyczące utworzenia jednostek pomocniczych i ich późniejszych przekształceń. Ważnym źródłem informacji były dane uzyskane bezpośrednio od członków badanych rad osiedli oraz Plan Miasta Łodzi, mapy analizowanych osiedli, a także strony internetowe, m.in.: Urzędu Miasta Łódź.

Badania dotyczyły działalność rad osiedlowych w dwóch ostatnich kadencjach, tj. od marca 2005 do czerwca 2013 r. i skupiały się przede wszystkim na ich samoocenie oraz postrzeganiu przez społeczności lokalne.

\subsection{Możliwości oddziaływania rad osiedlowych na przestrzeń Łodzi wynikające $\mathrm{z}$ uwarunkowań prawno-ekonomicznych}

Tradycja samorządu terytorialnego w Polsce to z jednej strony tradycja prawa miejskiego sięgająca średniowiecza, z drugiej tradycja prawa ziemskiego. Nowoczesna forma samorządu terytorialnego w zasadzie zaczęła tworzyć się w wieku XIX, jednakże pewne rozwiązania próbowano wprowadzić już u schyłku I Rzeczypospolitej. Dopiero po odzyskaniu niepodległości w 1918 r. przystąpiono do tworzenia instytucji samorządu terytorialnego, którego funkcjonowanie zahamowała II wojna światowa a później system komunistyczny okresu PRL. W latach transformacji społecznopolitycznej lat 90. w Polsce jednym z najważniejszych procesów była dewolucja państwa, zaś jej fundamentalnym składnikiem przywrócenie 
i rozwój samorządu terytorialnego. Po przystąpieniu do Unii Europejskiej samorząd terytorialny funkcjonuje także opierając się na Europejskiej Karcie Samorządu Terytorialnego, którą Polska ratyfikowała w 1993 r. Dzięki temu, podczas precyzowania zadań samorządu i jego funkcjonowania można korzystać z doświadczeń zagranicznych (Pająk 2003).

Zgodnie $\mathrm{z}$ definicją samorząd terytorialny jest to wyodrębniony w strukturze państwa związek społeczności terytorialnej, który jest powoływany do samodzielnego wykonywania administracji publicznej, wyposażony $\mathrm{w}$ środki materialne umożliwiające realizację nałożonych na niego zadań (Słownik podstawowych terminów samorządu terytorialnego 2007). Termin ten zawiera w sobie stwierdzenia o uprawnieniach jednostki do samostanowienia o sobie, określając równocześnie narzędzia do jego realizacji, w postaci środków materialnych.

Samorząd wykonuje zadania publiczne, które nie są zastrzeżone przez Konstytucję lub ustawy dla organów innych władz publicznych. Samorząd terytorialny powinien na obszarze swojego działania opierać się na silnej samorządności (aktywnej postawie cywilno-prawnej), w celu realizacji własnych zadań statutowych (Demokracja - samorzqdność - prawo 2007). Samorząd urzeczywistnia misję idei samorządności przez aktywizację społeczności terytorialnej oraz racjonalizuje działania władz publicznych. Według Gąciarza samorządność jest formą rządzenia stosowaną w społecznościach, zbiorowościach lub wspólnotach, które cieszą się określoną autonomią względem społeczeństwa globalnego i jego instytucji (Barański 2007). W ogólnym ujęciu idea samorządności zakłada, że wspólnoty lokalne są w stanie integrować interesy na określonej przestrzeni, dzięki dysponowaniu autonomicznymi środkami.

Gmina jest jednostką samorządu terytorialnego powołaną do wykonywania zadań publicznych w sposób samodzielny (Konstytucja Rzeczypospolitej Polskiej z dnia 2 kwietnia 1997 r.). Jednostkami pomocniczymi gminy są wspólnoty samorządowe działające w gminie, które na mocy ustawy z dnia 22 marca 1990 r. stanowią najniższy szczebel i tworzone są przez radę gminy (miasta) w celu wykonywania pewnych zadań. Uprawnienie to zostało przyznane radzie gminy i stanowi jej wyłączną kompetencję, której nie można scedować na inny organ. W ustawie dla określenia tych jednostek użyto pojęcia osiedle oraz dzielnica lub miasta na terenie gminy, natomiast sołectwa w gminach wiejskich.

Jednostki pomocnicze pełniące funkcję pomocniczą wobec organów gminy nie mają zagwarantowanej samodzielności, a ich zadaniem jest realizowanie polityki gminy. Ustawa w bardzo ogólnikowy sposób określa zasady działania jednostek pomocniczych, pozostawiając w tym względzie wolną rękę gminom. To gmina wyznacza jednostkom, poprzez uchwalenie statutu, zadania do zrealizowania, określa kompetencje i granice 
odpowiedzialności, zasady finansowania i pozyskiwania dodatkowych funduszy. Gmina decyduje również, czy na jej terenie w ogóle mają działać jednostki pomocnicze i w jaki sposób mogą być powoływane. Zadanie i kompetencje organów jednostki pomocniczej ustala rada gminy, stąd nie są one obligatoryjne we wszystkich miastach. Przepisy prawa nie określają skuteczności działań jednostek pomocniczych, która zależy przede wszystkim od stosunku władz miejskich do samorządu pomocniczego. Rady miejskie muszą stworzyć odpowiednie warunki i swobodę działań radom osiedlowym, bez której nawet najbardziej zaangażowani społecznicy w końcu zrezygnują z pracy na rzecz samorządu pomocniczego.

Ustawa określa dwie drogi tworzenia jednostek pomocniczych - można je określić, jako sposób „odgórny” i „oddolny” (DzU, 1990, nr 16, poz. 95). Obie możliwości są wykorzystywane przez polskie miasta. W wersji „odgórnej" to rada miasta decyduje o tym, że mają zaistnieć jednostki pomocnicze, wyznacza ich granice, przeprowadza konsultacje z mieszkańcami, ogłasza wybory i powołuje rady osiedli. Siatka rad osiedli pokrywa wówczas całe miasto. W sposobie „oddolnym” inicjatywa powołania jednostek pomocniczych należy do mieszkańców, którzy pewnego dnia postanawiają, że chcą zorganizować się $\mathrm{w}$ radę osiedla. Składają wówczas wniosek do rady miasta o powołanie jednostki i wyznaczają jej granice. Rolą miasta jest pilnowanie kwestii formalnych i udzielenie zgody na powołanie jednostki pomocniczej. Sieć rad osiedli nie musi wówczas pokrywać całego terenu miasta. W każdym przypadku wymagana jest uchwała rady gminy, a sposób tworzenia jednostki osiedlowej musi być zawarty w statucie gminy.

Zgodnie z ustawą, w statucie jednostki pomocniczej określa się w szczególności nazwę i obszar jednostki pomocniczej, zasady i tryb wyborów, a także organizację i zadania jej organów, zakres zadań przekazywanych jednostce przez gminę i sposób ich realizacji oraz zakres i formy kontroli i nadzoru organów gminy nad działalnością organów jednostki pomocniczej. Organem uchwałodawczym w osiedlu jest rada, ale może być również ogólne zebranie mieszkańców, jeżeli tak zostanie ustalone w statucie osiedla (art. 37 omawianej ustawy, DzU, 1990, nr 16, poz. 95). W kwestii liczby członków rady osiedlowej ma odpowiednie zastosowanie art. 17. Rada nie może przekraczać 21 radnych, a jej organem wykonawczym w osiedlu jest zarząd, na czele którego stoi przewodniczący, korzystający $\mathrm{z}$ ochrony prawnej przysługującej funkcjonariuszom publicznym. Może on uczestniczyć w pracach rady gminy, jednak bez prawa udziału w głosowaniu, na zasadach określonych w statucie gminy. Zgodnie z postanowieniami ustawy, rada gminy może ustalić zasady, na jakich członkom organu wykonawczego jednostki pomocniczej oraz członkom rady osiedla będzie przysługiwała dieta lub zwrot kosztów podróży służbowej. Rada gminy może ponadto upoważnić organ wykonawczy jednostki pomocniczej do 
załatwiania indywidualnych spraw z zakresu administracji publicznej (DzU, 1990, nr 16, poz. 95).

Jednostki pomocnicze w Łodzi (osiedla) zostały utworzone na podstawie przepisów ustawy z dnia 8 marca 1990 r. o samorządzie gminnym oraz Statutu Miasta Łodzi z dnia 23 listopada 2005 r. Wszystkim jednostkom nadano statuty określające ich organizację i zakres działania.

Obecnie na terenie Łodzi działa 36 jednostek pomocniczych miasta. Statut Miasta Łodzi zawiera ogólne postanowienia dotyczące funkcjonowania tego szczebla samorządu miejskiego. Działalność organów osiedla - rady osiedla i zarządu osiedla - podlega nadzorowi i kontroli w zakresie zgodności z prawem, które sprawuje Rada Miejska w Łodzi, a także Prezydent Miasta. Rady osiedla są instytucjonalnie związane z działaniami samorządu gminnego, który deleguje niektóre funkcje na swoje jednostki pomocnicze. Rada Miejska tworzy, łączy, dzieli i znosi jednostki pomocnicze, a także określa ich granice i nazwy. Podejmując takie działania musi brać pod uwagę istniejące uwarunkowania przestrzenne, tak aby obszar jednostki był zwarty terytorialnie, uwzględniać więzi społeczne łączące mieszkańców danego terenu, a uchwały podejmować po wcześniejszych konsultacjach z nimi.

Konsultacje mają na celu uzyskanie od mieszkańców opinii dotyczącej zasadności utworzenia, połączenia, podziału lub zniesienia jednostki pomocniczej, zakresu zadań i kompetencji jej organów oraz proponowanych granic i nazwy. Powinny one w szczególności obejmować publiczne ogłoszenie na danym terenie o zamiarze utworzenia, połączenia, podziału lub zniesienia jednostki, zorganizowanie zebrania mieszkańców z przedstawicielami Rady Miejskiej i Prezydentem, jak również możliwość zgłaszania przez mieszkańców uwag i wniosków do przewodniczącego Rady w okresie 30 dni od daty zebrania (Dz Urz. Woj. Łódzkiego, 2005, nr 23, poz. 148).

Przepisy statutu stanowią, że Rada Miejska zobowiązana jest do podjęcia procedury w sprawie utworzenia jednostki pomocniczej na pisemny wniosek co najmniej 200 mieszkańców obszaru mającego tworzyć nową jednostkę. Procedura w sprawie łączenia podziału lub zniesienia może być natomiast podjęta na pisemny wniosek co najmniej 5\% mieszkańców danego terenu, w sprawie zaś zmiany granic może także wnioskować rada osiedla. Jeżeli zmiana granic spowoduje przekroczenie 25\% zmiany liczby mieszkańców konieczne jest przeprowadzenie nowych wyborów do organu uchwałodawczego (Dz Urz. Woj. Łódzkiego, 2005, nr 23, poz. 148).

W myśl postanowień statutu organy miasta i jednostki organizacyjne Urzędu Miasta są zobowiązane do udzielania pomocy i wsparcia organom jednostek pomocniczych. Powinny zapewnić radzie i zarządowi osiedla pomieszczenie na siedzibę wraz z niezbędnym wyposażeniem i rozpatrywać zgłaszane przez nich wnioski i postulaty. 
Rada Miejska ustala termin przeprowadzania wyborów do rady osiedla. Może ona również rozwiązać ten organ w przypadku nie dokonania wyboru zarządu osiedla w przeciągu sześciu miesięcy od ogłoszenia wyborów, a także gdy dochodzi do powtarzających się, rażących naruszeń prawa (statut precyzuje sposób rozwiązania organu uchwałodawczego osiedla.

Z ustaleń statutu wynika, że przewodniczący rady osiedla zobowiązany jest do przedłożenia przewodniczącemu Rady Miejskiej uchwał tego organu w ciągu 14 dni od ich podjęcia. Tyle samo czasu ma przewodniczący zarządu osiedla aby przekazać uchwały prezydentowi. Mogą one zostać uchylone gdy zostały podjęte niezgodnie z prawem. Może się jednak zdarzyć, że wcześniej rada miejska lub prezydent wstrzyma ich wykonanie i przekaże do ponownego rozpatrzenia, wskazując zaistniałe uchybienia oraz termin załatwienia sprawy.

Gospodarka finansowa jednostek pomocniczych prowadzona jest na podstawie zatwierdzonych przez prezydenta planów finansowych, $\mathrm{w}$ ramach środków przyznanych w uchwale budżetowej rady miejskiej. Plany finansowe jednostek muszą być opracowywane zgodnie z procedurą uchwalania budżetu miasta. Prezydent zapewnia osiedlu także obsługę finansowo-księgową i prawną.

Rada Miejska może przekazać jednostce również mienie komunalne, ale wyłącznie do realizacji zadań ustalonych w uchwale rady o przekazaniu tego majątku. Wszelkie dochody płynące z przekazanego mienia komunalnego przeznaczane są $w$ ramach budżetu miasta na finansowanie zadań zaproponowanych przez radę osiedla (DzUrz Woj. Łódzkiego, 2005, nr 23, poz. 148).

W wyniku uchwał Rady Miejskiej Łodzi osiedlom nadano statuty określające ich organizację i zakres działania. Organami osiedla są: rada osiedla i zarząd osiedla.

Do zakresu działania osiedla należą sprawy publiczne o zasięgu lokalnym, w tym:

- inicjowanie, wspieranie oraz organizowanie działań mających na celu zaspokajanie potrzeb mieszkańców osiedla,

- opiniowanie projektu budżetu Miasta,

- uczestnictwo przedstawiciela rady osiedla, będącego pracownikiem Urzędu Miasta Łodzi lub miejskiej jednostki organizacyjnej, w komisjach przetargowych organizowanych przez miejskie jednostki organizacyjne,

- podejmowanie, wspieranie działań na rzecz ochrony środowiska, przyrody i zieleni miejskiej na terenie osiedla,

- współdziałanie z organami miasta, policją, strażą miejską i strażą pożarną w zakresie utrzymania ładu, porządku publicznego, bezpieczeństwa oraz przeciwdziałania patologiom społecznym na terenie osiedla, 
- współdziałanie z organizacjami społecznymi i innymi podmiotami w tworzeniu na terenie osiedla świetlic i klubów osiedlowych dla dzieci, młodzieży i pozostałych mieszkańców,

- współdziałanie $\mathrm{z}$ administracjami nieruchomości istniejącymi na terenie osiedla w zakresie zarządzania i dbałości o stan mienia komunalnego, wskazywania niezbędnych, priorytetowych do wykonania remontów, udziału w odbiorze wykonywanych prac,

- współdziałanie $\mathrm{z}$ organizacjami pozarządowymi w sprawach istotnych dla osiedla,

- ocenę funkcjonowania miejskich jednostek organizacyjnych działających na terenie osiedla w sferze użyteczności publicznej i wnioskowanie o ich kontrolę, z wyłączeniem jednostek organizacyjnych, które zakresem działania obejmują całe miasto,

- wyrażanie opinii oraz występowanie z postulatami i wnioskami do organów Miasta Łodzi i miejskich jednostek organizacyjnych we wszystkich sprawach należących do miasta, a dotyczących osiedla,

- występowanie do przewodniczącego Rady Miejskiej w Łodzi, komisji rady, radnych oraz Prezydenta Miasta Łodzi z wnioskami o podjęcie inicjatywy uchwałodawczej w sprawach dotyczących osiedla,

- wnioskowanie o przekazanie zadań oraz składników mienia komunalnego w celu współdziałania przy realizacji spraw, w części dotyczącej osiedla, z zakresu: placów zabaw, świetlic, klubów, boisk i terenów rekreacyjnych,

- uczestnictwo przedstawiciela rady osiedla w radach programowych miejskich instytucji kultury, oświatowych i sportowo-rekreacyjnych działających na obszarze osiedla,

- zgłaszanie wniosków i opinii do studium uwarunkowań i kierunków zagospodarowania przestrzennego miasta oraz projektów miejscowych planów zagospodarowania przestrzennego w trakcie ich sporządzania,

- opiniowanie projektów uchwał i innych rozstrzygnięć organów miasta, w części dotyczącej osiedla, w sprawach:

- studium uwarunkowań i kierunków zagospodarowania przestrzennego miasta oraz projektu miejscowego planu zagospodarowania przestrzennego,

- zbywania nieruchomości gruntowych oraz lokali użytkowych będących własnością miasta,

- lokalizacji inwestycji miejskich wraz z oceną ich oddziaływania na środowisko na terenach będących własnością miasta,

- planu rzeczowego i finansowego budowy i remontów obiektów komunalnych, w tym dróg i ulic oraz ich oświetlenia, wodociągów, kanalizacji, sieci zaopatrujących w energię elektryczną i cieplną budynki 
mieszkalne, urządzeń sportowych; planu rzeczowego i finansowego zakładania i utrzymania zieleni miejskiej oraz terenów rekreacyjnych, miasta,

przeznaczania wolnych lokali użytkowych będących własnością

- zmiany przeznaczenia miejskich obiektów oświatowych, służby zdrowia, kultury, pomocy społecznej, sportu i rekreacji,

- lokalizacji punktów handlowych, gastronomicznych, usługowych i targowisk oraz punktów sprzedaży i konsumpcji alkoholu oraz cofania wydanych w tym zakresie zezwoleń, przebiegu tras linii komunikacyjnych lokalnego transportu zbiorowego oraz rozmieszczenia przystanków;

- wykonania budżetu miasta w zakresie zadań własnych realizowanych przez Urząd Miasta Łodzi.

Rady osiedli mogą także wnioskować o realizację zadań inwestycyjnych lub remontowych $w$ ramach procedury budżetowej oraz w trybach:

- konkursu na zadania inwestycyjne,

- wskazywania zadań inwestycyjnych lub remontowych w oparciu o środki określone zgodnie z przyjętym algorytmem.

Zgodnie ze statutem osiedli, rady osiedli będą decydowały o wyborze zadań do realizacji w różnych dziedzinach, co umożliwia dokonywanie wyboru zadań ściśle związanych $\mathrm{z}$ potrzebami społeczności lokalnych i zaktywizuje mieszkańców poprzez szersze ich włączenie w proces zarządzania miastem. Zakres merytoryczny tych decyzji dotyczy:

- prac remontowych żłobków i przedszkoli, szkół podstawowych, gimnazjów, szkół ponadgimnazjalnych oraz innych placówek oświatowych;

- prac remontowych chodników oraz dróg wraz z oświetleniem;

- budowy lub modernizacji ogródków jordanowskich;

- konserwacji zieleńców wraz z małą architekturą;

- poprawy stanu bezpieczeństwa, ładu i porządku;

- działań na rzecz osób niepełnosprawnych;

- działalności kulturalnej i sportowo-rekreacyjnej (strona internetowa Urzędu Miasta Łodzi: http://bip.uml.lodz.pl z dn. 21.02.2013).

Statut jednostki pomocniczej gminy jest aktem prawa miejscowego i reguluje jej ustrój wewnętrzny. Nie oznacza to jednak, że jednostki pomocnicze na terenie jednego miasta mają tożsame zadania i kompetencje (Słownik podstawowych terminów samorzq̨du terytorialnego 2007). Każda jednostka pomocnicza funkcjonująca na terenie Łodzi ma odrębny statut uchwalony przez radę miejską. Do obligatoryjnych regulacji statutowych należy określenie nazwy i obszaru jednostki, zasad i trybu wyboru do jej organów, organizacji i zadań organów jednostki, a także wskazanie zakresu zadań przekazywanych jednostce, a także sposób ich realizacji. 
Teoretyczny zakres zadań, w których realizacji biorą udział jednostki pomocnicze, jest stosunkowo szeroki - głównie z uwagi na możliwość wnioskowania oraz opiniowania działań jednostek organizacyjnych gminy. Jednak faktyczny wpływ na zaspokajanie potrzeb wspólnoty samorządowej jest marginalny - ograniczony do uprawnień o charakterze niewiążącym. Podstawową przyczyną takiego stanu rzeczy jest subsydiarna pozycja jednostek pomocniczych w stosunku do gminy, a także brak posiadania przez nie osobowości prawnej, co skutkuje pośredniością realizacji działań własnych, tzn. realizuje je gmina. Ponadto jednostki pomocnicze, w odróżnieniu od władz gminy, nie dysponują rozbudowanym i kompetentnym aparatem pomocniczym.

Przewodniczący 14 rad osiedlowych, z którymi przeprowadzono wywiady, widzą zadania i funkcje rad w sposób bardziej ograniczony, wymieniając osiem celów i zadań rad. Najwięcej respondentów określa je jako pomoc mieszkańcom w rozwiązywaniu ich problemów, zaspokajaniu potrzeb i realizacji inicjatyw (64\%) oraz w ściąganiu i opiniowaniu inwestycji i kontroli ich wykonywania na terenie osiedla (36\%).Ważnym zadaniem rad jest organizacja różnego rodzaju imprez, które są pewnym sposobem wzajemnego poznania mieszkańców i członków rady, formą kontaktów i budowania więzi społecznych (29\%). Na podobnym poziomie respondenci wymienili współpracę z mieszkańcami i organizacjami oraz Urzędem Miast (21\%) i dbanie o estetykę i stan infrastruktury osiedla (21\% badanych). Pozostałe z wymienionych celów działania rad to: monitorowanie osiedla i rozwiązywanie konfliktów lokalnych (14\% ankietowanych), podział środków na remonty i inwestycje (7\%) oraz dbanie o bezpieczeństwo na osiedlu (7\% pytanych). Przewodniczący stwierdzali również, że działania są zgodne ze statutem jednostki pomocniczej $(21 \%$ badanych),

Wymienione przez przewodniczących rad osiedlowych cele i zadania są dość ogólne i mieszczą się w statutach jednostek osiedlowych. Są one formułowane dość wąsko na miarę rzeczywistych możliwości działania rad, które zależą nie tylko od sformułowań i zapisów prawno-ekonomicznych, ale również innych jeszcze czynników.

\subsection{Determinanty genetyczno-gospodarcze oddziaływania rad osie- dlowych na kształtowanie dysproporcji przestrzennych w Lodzi}

\subsubsection{Geneza podziału przestrzeni miasta}

Podział miasta na jednostki samorządowe ma uzasadnienie nie tylko w procesie rozwoju społeczeństwa obywatelskiego i lepszego zarządzania miastem, ale także w jego dziedzictwie historycznym. Podział ten, w swo- 
ich podstawach teoretycznych, powinien odwoływać się z jednej strony do genetycznej struktury miasta, z drugiej do współczesnych relacji wiążących poszczególne jego obszary. Utrwalone w przestrzeni miejskiej dawne jednostki osadnicze mogą być łączone $\mathrm{w}$ większe zespoły osiedlowe, jeśli wynika to z innych przesłanek, według kryterium podobieństwa form przestrzennych oraz relacji je wiążących.

Pierwsza uchwała rady miejskiej w sprawie utworzenia samorządów osiedlowych w gminie Łódź weszła w życie 20 marca 1991 r. Zgodnie z jej treścią zamiar powstania samorządu mógł być zgłaszany na wniosek:

1 - komitetów domowych „w liczbie co najmniej 1 komitet na 1000 mieszkańców osiedla" i obejmujących swoim działaniem co najmniej 10\% mieszkańców osiedla (tryb I),

2 - mieszkańców osiedla „w liczbie co najmniej 25 osób na każde 10.000 mieszkańców", tylko wtedy, gdy nie składano wniosku ze strony komitetów domowych (tryb II).

W ordynacji wyborczej tych wyborów do organów samorządów osiedlowych wskazano radę osiedla jako organ wykonawczy, organem zaś uchwałodawczym mogło być zebranie delegatów komitetów domowych (tryb I) lub ogólne zebranie mieszkańców (tryb II), (Uchwała nr XIII/143/91 Rady Miejskiej w Łodzi z dnia 20 marca 1991 r.).

Tego samego dnia uchwalono inną uchwałę w sprawie utworzenia sołectw na terenie gminy Łódź. Były to terytorialne jednostki pomocnicze, które tworzyła, łączyła, znosiła oraz ustalała ich nazwy i granice rada miejska, po przeprowadzeniu konsultacji z mieszkańcami lub z ich inicjatywy. Organami sołectwa wybieranymi na 4 lata były zebranie wiejskie i sołtys (Uchwała nr XIII/144/91 Rady Miejskiej w Łodzi z dnia 20 marca 1991 r.).

Pierwszy z podziałów przestrzennych na jednostki samorządowe Łodzi opracowany przez grupę geografów z UŁ, powstał na zlecenie Urzędu Miasta w 1991 r. (Koter i in. 1991). Autorzy przyjęli następujące kryteria:

1) historyczne - tworzenie jednostek na podstawie historycznie ukształtowanych jednostek osadniczych i w ich granicach prawno-własnościowych, z zachowaniem nazw miejscowych.

2) administracyjne - ściśle skorelowany z projektowanym podziałem miasta na nowe dzielnice administracyjne (delegatury), a na obszarach nowo przyłączonych do Łodzi oparty na sołectwach, które mają długą tradycję i ukształtowane więzi lokalne.

3) statystyczne - zgodny w miarę możliwości z istniejącym już podziałem Łodzi na jednostki bilansowe, co ma wielkie znaczenie dla tworzenia dokumentacji, prognoz rozwojowych oraz badań porównawczych. 
4) morfologiczno-funkcjonalne - uwzględnienie zróżnicowanych form zabudowy: wielkomiejskiej (kamienniczej i blokowej), przemysłowej, jednorodzinnej (willowej, segmentowej, podmiejskiej) oraz rolniczo-zagrodowej.

5) demograficzne - górna granica liczby ludności na poziomie ok. 40 tys. mieszkańców (taką liczbę przyjęto w wyborach samorządowych w czerwcu 1990 r. dla różnicowania okręgów, w których dokonywano wyborów metodą bezpośrednią).

Zaproponowany podział obejmował 69 jednostek samorządowych (ryc. 3.1), różniących się istotnie pod względem powierzchni, która była zależna od położenia i gęstości zaludnienia poszczególnych części miasta (Koter i in. 1991).

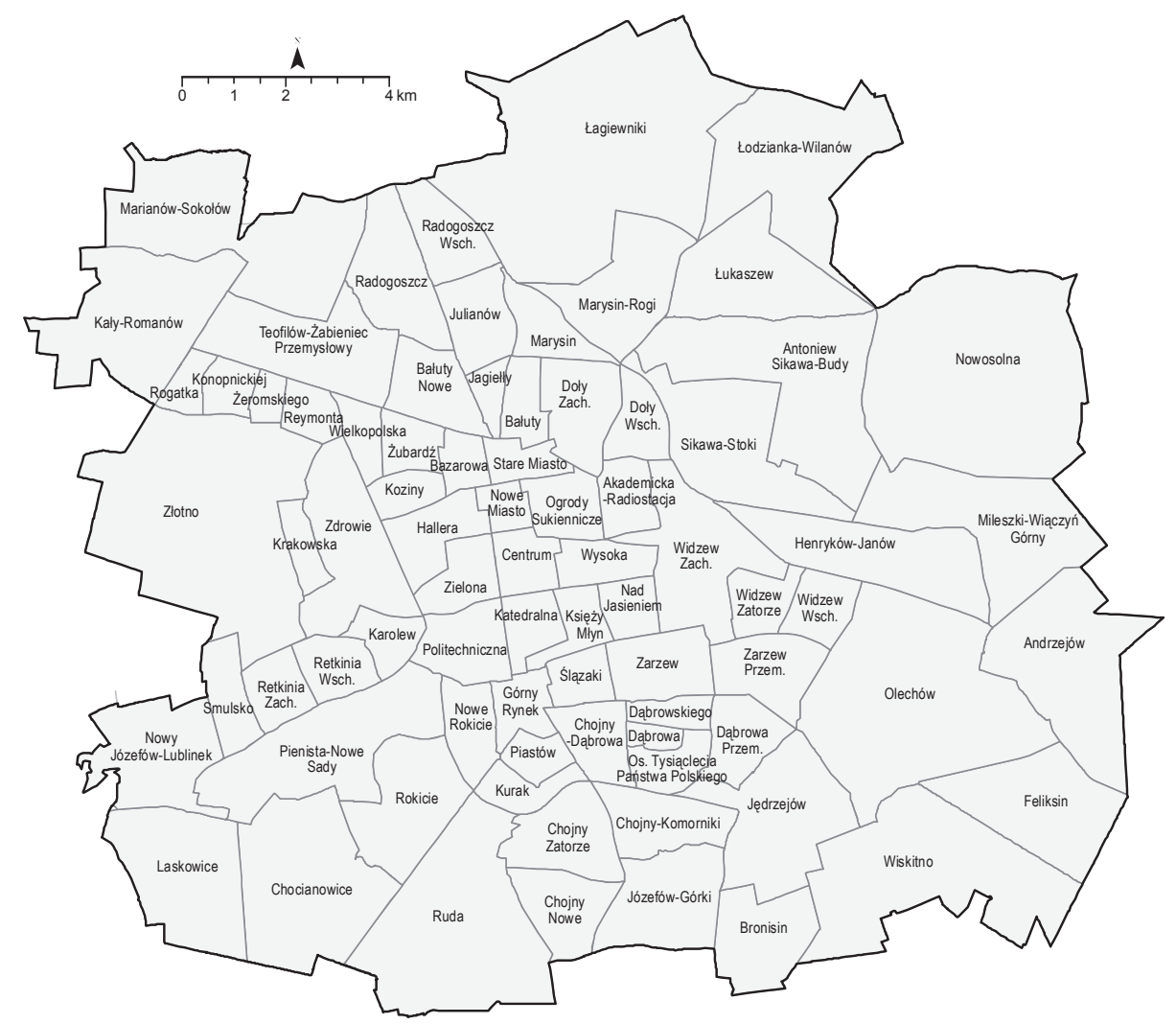

Ryc. 3.1. Jednostki samorządowe Łodzi (osiedla) według podziału z $1991 \mathrm{r}$. Źródło: opracowanie własne na podstawie: Koter i in. 1991 
W 1995 r. Rada Miejska w Łodzi podjęła drugą uchwałę w sprawie utworzenia jednostek pomocniczych gminy - osiedli. Weszła ona w życie 7 stycznia 1996 r. Zgodnie z jej ustaleniami na terenie Gminy Łódź utworzono nowe jednostki pomocnicze, których ukonstytuowanie nastąpiło w chwili przeprowadzenia na danym terytorium ważnych wyborów do rady osiedla. W myśl uchwały istniejące na terenie Gminy Łódź sołectwa miały działać na dotychczasowych zasadach. Ponadto każdej jednostce pomocniczej nadano odrębny statut (Uchwała nr XIX/210/95 Rady Miejskiej w Łodzi z dnia 4 października 1995).

Kolejna (trzecia) uchwała Rady Miejskiej powstała pięć lat później. Zniosła ona na terenie Łodzi jednostki pomocnicze utworzone wcześniej (osiedla i sołectwa), a w ich miejsce powołano 35 jednostek pomocniczych miasta - osiedla (Uchwała nr XXXIV/754/2000 Rady Miejskiej w Łodzi z dnia 5 kwietnia 2000 r.). Warto dodać, iż do roku 2000 osiedla stanowiły odrębne jednostki w strukturze pomocniczej Miasta (Uchwała nr LV/1052/05 Rady Miejskiej w Łodzi z dnia 12 października 2005 r.). W 2005 r. nastąpiła zmiana liczby jednostek pomocniczych na podstawie wniosku mieszkańców, Osiedle nr 18 podzielono na osiedle im. Montwiłła Mireckiego oraz Zdrowie-Mania, ustalając tym samym aktualną liczbę osiedli na 36.

Uchwałodawcy nowego podziału podkreślali jego zalety w postaci zachowania odrębności tworzonych jednostek pomocniczych w zakresie tradycji historyczno-kulturowej, układów przestrzennych, typów zabudowy oraz poziomu infrastruktury technicznej. Podział ten został jednak surowo oceniony przez wybitnego znawcę przestrzeni historycznej Łodzi prof. Marka Kotera, który słusznie napisał: „Czynności tej dokonano arbitralnie, na zasadzie mechanicznego łączenia z reguły dwóch sąsiednich jednostek, bez brania pod uwage jakichkolwiek kryteriów historycznych, morfologicznych i społecznych. W efekcie powstały jednostki mające się nijak do tradycyjnych struktur osadniczych, w których trudno oczekiwać emocjonalnego poczucia tożsamości terytorialnej, żywszych więzi oraz wspólnych interesów grupowych. Szczytem zaś odhumanizowania tego podziału było pozbawienie wielu jednostek tradycyjnych nazw własnych" [...] „W wyniku sprzeciwu mieszkańców większość ponumerowanych osiedli [z wyjątkiem jednego - uzupełnienie A. S.] przyjęła później nazwy własne" (Koter 2009). 


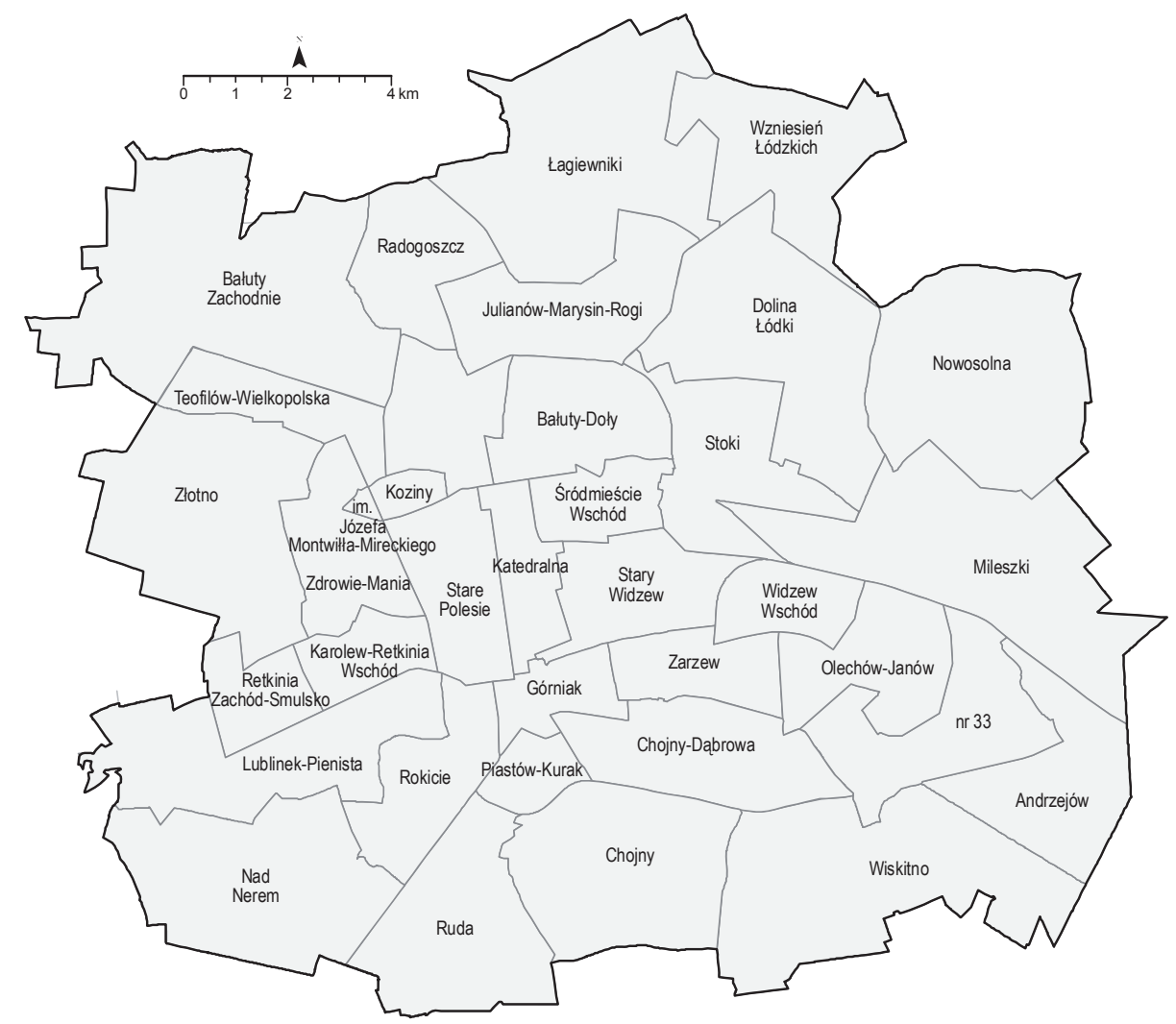

Ryc. 2. Jednostki pomocnicze Łodzi w 2014 r.

Źródło: opracowanie własne na podstawie Łódzkiego Internetowego Systemu Informacji o Terenie (www.gis.mapa.lodz.pl)

3.3.2. Położenie, zagospodarowanie i dominujące funkcje jednostek pomocniczych

Łódź jest zbiorem wielu jednostek osadniczych o odmiennej genezie i rozwoju historycznym, znacznych odrębnościach funkcjonalnych, zróżnicowanych cechach urbanistycznych i architektonicznych, a także różnym poziomie zagospodarowania. Mieszkańcy miasta tworzą pewne społeczności lokalne, mniej lub bardziej zintegrowane, niekiedy o znacznym poczuciu odrębności. Jest to niewątpliwe rezultat zróżnicowanych losów poszczególnych części miasta $\mathrm{w}$ procesie rozwoju historycznego oraz odmienności ich współczesnych struktur społecznych.

Dzieje rozwoju Łodzi pokazują, że nie jest to miasto jednorodne, chociaż dzisiaj tworzy jeden system miejski. Przestrzeń osadnicza Łodzi utworzyła się z odrębnych w przeszłości jednostek osadniczych: miast (np. Łódź, Ruda), wsi (np. Bałuty, Nowosolna), dawnych folwarków (np. Julianów, 
Łagiewniki), osad fabrycznych (np. Księży Młyn, Łódka) i osiedli mieszkaniowych (np. Teofilów, Doły), których ślady w postaci specyficznych cech morfologicznych oraz dawnego nazewnictwa zostały utrwalone $\mathrm{w}$ przestrzeni fizycznej, a częściowo także i społecznej. W poszczególnych częściach miasta wytworzyły się więzi lokalne oparte na przekazie międzypokoleniowym, poczuciu tożsamości terytorialnej lub na relacjach funkcjonalnych wynikających z interesów grupowych bądź też na jednym i drugim.

Niestety, utworzenie 36 jednostek osiedlowych, na zasadzie przypadkowego łączenia często różnych genetycznie i społecznie organicznych osiedli (patrz podział M. Kotera z 1991 r.) sprawiło, że rady osiedlowe mają do czynienia z jednostkami o heterogenicznej strukturze wewnętrznej (morfogenetycznej, funkcjonalnej i społecznej), a między sobą różnią się wielkością powierzchni, liczbą i strukturą społeczną ludności oraz pełnionymi funkcjami. Podstawowe zróżnicowanie liczby ludności jednostek pomocniczych oraz dominującego w nich typy zabudowy i funkcji zaprezentowano $\mathrm{w}$ tabeli 3.1. Pogrubionym drukiem zapisano jednostki pomocnicze, w których prowadzono badania ankietowe.

Przestrzeń Łodzi, w tradycjach administracyjnych, była podzielona na dzielnice, których liczba od czasów międzywojennych ulegała kilkakrotnej zamianie. Do 1993 roku funkcjonowało pięć dzielnic (Bałuty, Górna, Polesie, Śródmieście i Widzew), które z dniem 1 stycznia tego roku zostały formalnie zniesione. Istniejące jednostki pomocnicze (osiedla) wpisują się w granice dawnych dzielnic miasta, które są mocno utrwalone w świadomości mieszkańców Łodzi ( ryc. 3.2, tab. 3.1.).

Jednostki osiedlowe zajmują różne miejsca w przestrzeni miasta, z czego wynikają istniejące już dysproporcje w ich zagospodarowaniu oraz rola jaką spełniają dla całości miejskiej. Konsekwencje położenia oraz morfogenetyczny charakter jednostek pomocniczych definiują najważniejsze do rozwiązania problemy i działanie rad osiedlowych. Najogólniej można wyróżnić położenie jednostek pomocniczych w trzech strefach miasta: 1-peryferycznej, 2 - miejskiej zewnętrznej, 3 -śródmiejskiej centralnej.

Pierwsze, dotyczy 13 osiedli tj. 36\% wszystkich jednostek (Bałuty Zachodnie, Łagiewniki, Dolina Łódki, Nowosolna, Mileszki, Osiedle Nr 33, Andrzejów, Wiskitno, Nad Nerem, Lublinek-Pienista, Retkinia ZachódSmulsko i Złotno). Historia miejskości tych obszarów wiąże się z ostatnią inkorporacją nowych terenów do Łodzi (w 1988 r.), stąd zewnętrzne granice jednostek są równocześnie granicami administracyjnymi miast. Zajmują one relatywnie duże powierzchnie, w których dominują tereny otwarte w postaci użytków rolnych, nieużytków i powierzchni leśnych, a tereny zainwestowane koncentrują się wzdłuż dróg wylotowych z miasta, w postaci zurbanizowanych dawnych wsi lub współczesnych osiedli wolnostojącej bądź zwartej zabudowy jednorodzinnej (np. Łagiewniki). 
Tabela 3.1

Jednostki pomocnicze Łodzi według liczby mieszkańców, charakteru zabudowy i dominujących funkcji w strukturze przestrzennej miasta

\begin{tabular}{|c|c|c|c|c|c|c|c|}
\hline Lp. & $\begin{array}{c}\text { Dawne } \\
\text { Delegatury } \\
\text { UMŁ }\end{array}$ & $\begin{array}{l}\text { Nazwa } \\
\text { Osiedla }\end{array}$ & $\begin{array}{c}\text { Liczba } \\
\text { mieszkań- } \\
\text { ców }\end{array}$ & $\begin{array}{c}\text { Zabudowa } \\
\text { blokowa } \\
(\%)\end{array}$ & $\begin{array}{c}\text { Zabudowa } \\
\text { czynszowa } \\
(\%)\end{array}$ & $\begin{array}{c}\text { Zabudowa } \\
\text { jedno- } \\
\text { rodzinna } \\
(\%)\end{array}$ & $\begin{array}{l}\text { Dominują- } \\
\text { ce funkcje } \\
\text { osiedla }\end{array}$ \\
\hline 1 & \multirow{8}{*}{ 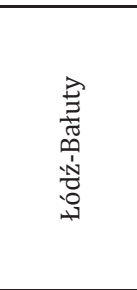 } & Bałuty Zachodnie & 6304 & 0 & 50 & 50 & U-P-R \\
\hline 2 & & Radogoszcz & 32765 & 80 & 0 & 20 & $\mathrm{M}-\mathrm{U}$ \\
\hline 3 & & Łagiewniki & 1692 & 0 & 0 & 100 & R-M \\
\hline 4 & & Marysin-Julianów-Rogi & 11951 & 0 & 25 & 75 & M-WR \\
\hline 5 & & Bałuty-Doły & 47859 & 70 & 30 & 0 & $\mathrm{M}-\mathrm{U}$ \\
\hline 6 & & Bałuty-Centrum & 53524 & 45 & 55 & 0 & $\mathrm{M}-\mathrm{U}$ \\
\hline 7 & & Teofilów-Wielkopolska & 50640 & 90 & 10 & 0 & $\mathrm{M}$ \\
\hline 8 & & Wzniesień Łódzkich & 1273 & 0 & 0 & 100 & R-M \\
\hline 9 & \multirow{8}{*}{ 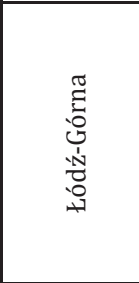 } & Nad Nerem & 1042 & 0 & 0 & 100 & R-U-M \\
\hline 10 & & Ruda & 11471 & 0 & 35 & 65 & M-WR \\
\hline 11 & & Chojny & 34829 & 65 & 20 & 15 & $\mathrm{M}-\mathrm{U}$ \\
\hline 12 & & Rokicie & 18917 & 50 & 30 & 20 & $\mathrm{M}$ \\
\hline 13 & & Górniak & 22152 & 30 & 70 & 0 & U-M \\
\hline 14 & & Piastów-Kurak & 22808 & 70 & 30 & 0 & $\mathrm{M}$ \\
\hline 15 & & Chojny-Dąbrowa & 54208 & 70 & 25 & 5 & $\mathrm{M}$ \\
\hline 16 & & Wiskitno & 3079 & 0 & 0 & 100 & $\mathrm{R}-\mathrm{M}$ \\
\hline 17 & \multirow{8}{*}{ 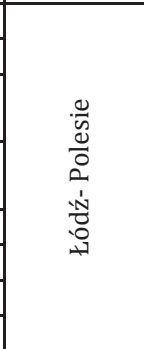 } & Złotno & 7001 & 0 & 20 & 80 & R-M-WR \\
\hline 18 & & Zdrowie -Mania & 3086 & 0 & 5 & 95 & WR-M \\
\hline 19 & & $\begin{array}{l}\text { im. J. Montwiłła- Mirec- } \\
\text { kiego }\end{array}$ & 1986 & 0 & 95 & 5 & $\mathrm{M}$ \\
\hline 20 & & $\begin{array}{l}\text { Karolew-Retkinia- } \\
\text {-Wschód } \\
\end{array}$ & 41994 & 85 & 15 & 5 & $\mathrm{M}-\mathrm{U}$ \\
\hline 21 & & Retkinia Zachód-Smulsko & 28952 & 95 & 0 & 5 & $\mathrm{M}$ \\
\hline 22 & & Lublinek-Pienista & 3544 & 60 & 0 & 40 & R-U-M \\
\hline 23 & & Stare Polesie & 40339 & 30 & 70 & 0 & $\mathrm{M}-\mathrm{U}$ \\
\hline 24 & & Koziny & 11841 & 90 & 10 & 0 & $\mathrm{M}-\mathrm{U}$ \\
\hline 25 & \multirow{2}{*}{$\begin{array}{l}\text { Łódź- } \\
\text { Śródmie- } \\
\text { ście }\end{array}$} & Katedralna & 46708 & 25 & 75 & 0 & U-M \\
\hline 26 & & Śródmieście - Wsch. & 22727 & 10 & 90 & 0 & U-M \\
\hline 27 & \multirow{10}{*}{ 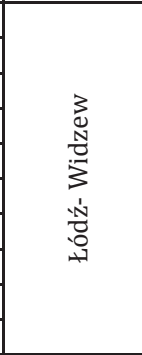 } & Dolina Łódki & 1630 & 0 & 0 & 100 & $\mathrm{R}-\mathrm{U}$ \\
\hline 28 & & Nowosolna & 3139 & 0 & 0 & 100 & R-M \\
\hline 29 & & Mileszki & 1543 & 0 & 0 & 100 & $\mathrm{R}-\mathrm{M}$ \\
\hline 30 & & Olechów-Janów & 18733 & 100 & 0 & 0 & $\mathrm{M}$ \\
\hline 31 & & Zarzew & 22109 & 70 & 30 & 0 & $\mathrm{M}-\mathrm{U}$ \\
\hline 32 & & Stary Widzew & 26173 & 15 & 85 & 0 & U-M \\
\hline 33 & & Stoki & 10882 & 0 & 25 & 75 & $\mathrm{M}-\mathrm{U}$ \\
\hline 34 & & Andrzejów & 5595 & 0 & 10 & 90 & M-R \\
\hline 35 & & Widzew-Wschód & 42429 & 90 & 5 & 5 & $\mathrm{M}$ \\
\hline 36 & & Osiedle Nr 33 & 801 & 0 & 0 & 100 & R-U \\
\hline
\end{tabular}

Funkcje dominujące: $\mathrm{U}$ - usługowe, $\mathrm{P}$ - przemysłowe, WR - wypoczynkowo-rekreacyjne, $\mathrm{R}$ - rolnicze.

Źródło: opracowanie własne na podstawie Zarządzenia nr 2952/V/09 Prezydenta Miasta Łodzi z dnia 26 marca 2009 r. 
Równocześnie przy dużej powierzchni jednostek liczba ich mieszkańców nie jest duża i oscyluje między 0,8 tys. (Osiedle Nr 33) a 7 tys. osób (Złotno), co sprawia, że gęstość zaludnienia jest tu bardzo niska, bardziej charakterystyczna dla obszarów wiejskich niż miejskich. Jednostki peryferyczne w strukturze przestrzenno-funkcjonalnej miasta spełniają najczęściej funkcje rolnicze, mieszkaniowe, wypoczynkowo-rekreacyjne, rzadziej usługowe (handlu hurtowego i wielkopowierzchniowego oraz komunikacyjne) i przemysłowe.

Jednostki peryferyjne stanowią przede wszystkim wewnętrzne zaplecze rozwoju centrum miejskiego (rdzenia miasta), ale też są atrakcyjne dla oddziaływań zewnętrznych, stąd ich przestrzeń jest przedmiotem gry różnych sił społecznych i ekonomicznych. Cechy tych obszarów stawiają przed radami osiedlowymi specyficzne zadania do rozwiązania wynikające $\mathrm{z}$ procesu intensywnej przestrzennej suburbanizacji wewnętrznej. Podstawowymi problemami są tutaj sposób zagospodarowania przestrzeni (infrastruktura drogowa, komunikacyjna, media techniczne, ochrona środowiska itp.) oraz integracja społeczna nowych mieszkańców z miejscem i sąsiadami.

Położenie w strefie 2 - miejskiej zewnętrznej, dotyczy jednostek pomocniczych, które zajmują tereny bezpośrednio przylegające do kolei obwodowej lub pierwotnej osi rozwojowej miasta (dawnego traktu piotrkowskiego) na jego krańcu południowym i północnym, a ich najintensywniejsze zagospodarowanie zapoczątkowane zostało w okresie 20-lecia międzywojennego i kontynuowane $\mathrm{w}$ okresie PRL. Takim położeniem charakteryzuje się również 13 jednostek pomocniczych (Radogoszcz, Julianów-Marysin-Rogi, Stoki, Widzew-Wschód, Olechów-Janów, ChojnyDąbrowa, Chojny, Ruda, Rokicie, Karolew-Retkinia-Wschód, Zdrowie Mania, Im. Montwiłła-Mireckiego i Teofilów-Wielkopolska), których granice w mniejszym lub większym stopniu wypełnia zwarta już tkanka miejska prezentująca różne formy zabudowy oraz stopień zużycia, zależny od jej wieku. Funkcjonalnie dominuje mieszkalnictwo - starsze zwarte wielorodzinne (kamienice) i jednorodzinne lub młodsze blokowe - oraz usługi wbudowane i wielkopowierzchniowe bądź funkcje wypoczynkowo-rekreacyjne (tereny zieleni urządzonej: parki, obiekty wypoczynkowe i sportowe, cmentarze). W tej strefie położone są jednostki pomocnicze największe pod względem ludnościowym, których tkankę utworzyły wielkopłytowe blokowiska, wybudowane w okresie PRL (Chojny-Dabrowa - 54 tys., TeofilówWielkopolska - 51 tys., Widzew-Wschód, Karolew-Retkinia-Wschód, każda po - 42 tys. mieszkańców), ale także jednostki małe, liczące po kilka tysięcy mieszkańców (im. J. Montwiłła-Mireckiego, Zdrowie-Mania, Stoki, Ruda), składające się z osiedli mieszkaniowych okresu międzywojennego 
i jednorodzinnej zabudowy współczesnej z ostatnich kilkudziesięciu lat. Tereny jednostek pomocniczych strefy drugiej są morfogenetycznie złożone lub złożone wielokrotnie z różnych układów osadniczych, często nie mających ze sobą nic wspólnego, co ujawnia się w silnych dysproporcjach przestrzennych i kontrastach społecznych. Ta ich złożona struktura sprzyja wewnętrznym sytuacjom konfliktowym, których przyczyną są zróżnicowane potrzeby mieszkańców poszczególnych, mało spójnych, części składowych. Różnice w charakterze zabudowy i stopniu jej dekapitalizacji oraz odmienne problemy społeczne, uniemożliwiają określenie wspólnych cele priorytetowych. Rozwiązywanie przez rady osiedlowe sprzeczności, przy ograniczonych możliwościach działania formalnego (wynikających z prawnych kompetencji jednostek) oraz środkach ekonomicznych, często przerasta ich możliwości.

Ostatnie 10 jednostek pomocniczych położonych jest w strefie 3 śródmiejskiej centralnej (Bałuty Centrum, Koziny, Bałuty-Doły, Śródmieście-Wschód, Stary Widzew, Katedralna, Stare Polesie, Zarzew, Górniak i Piastów-Kurak), która obejmuje obszary najintensywniejszego i najstarszego zainwestowania miejskiego, generalnie rozłożonego wewnątrz kolei obwodowej. Istniejące tutaj jednostki pomocnicze skupiają ponad 300 tys. mieszkańców a gęstość zaludnienia jest najwyższa - bliska 3 tys. os. $/ \mathrm{km}^{2}$. Funkcje jednostek pomocniczych, z wyjątkiem jednaj, są złożone: mieszkaniowo-usługowe (np. Bałuty Centrum, Doły, Stare Polesie), usługowo-mieszkaniowe (Katedralna, Śródmieście Wschód, Górniak, Stary Widzew) lub mieszkaniowe (Piastów-Kurak). Działanie rad osiedlowych jest w związku z tym bardziej utrudnione, ponieważ poszczególne instytucje mają wzajemnie sprzeczne interesy a ich działalność niejednokrotnie pozostaje w konflikcie z mieszkańcami. Wśród zabudowy tych obszarów znajdują się największe i najbardziej reprezentacyjne kamienice śródmiejskie, w większości wymagające renowacji, z którymi silnie kontrastują kamienice biedne i zdekapitalizowane oraz nowoczesne budynki administracyjno-usługowa kształtującego się nowego centrum miasta (Katedralna, Śródmieście-Wschód, Stare Polesie). W obszarach bardziej oddalonych od ścisłego centrum, skupionego wzdłuż starej osi ulicy Piotrkowskiej oraz nowej ulicy Piłsudskiego, dominuje starsza zabudowa blokowa, w postaci powojennych osiedli spółdzielczych (Koziny, Bałuty-Doły, PiastówKurak),, a także silnie zużyte budynki czynszowe rozłożone wzdłuż ważniejszych ulic poszczególnych jednostek pomocniczych, w których zamieszkuje ludność biedna, często pozbawiona pracy (Stary Widzew, Stare Polesie, Górniak, Bałuty Centrum). Strefa śródmiejska centralna stanowi obszar rdzeniowy Łodzi i województwa łódzkiego, w której koncentruje się większość funkcji metropolitalnych oraz innych funkcji, głównie usługowych najwyższego rzędu. Bardzo mało jest tutaj terenów zieleni, zabu- 
dowa starsza jest silnie skoncentrowana i wypełnia maksymalnie działki siedliskowe, tworząc charakterystyczne podwórka wielkomiejskie, z jednej strony skrywające biedę mieszkających tutaj ludzi, z drugiej, w tych zrewitalizowanych, bogactwo kancelarii adwokackich, prywatnych klinik lekarskich, eleganckich sklepów czy restauracji. W obszarach tej strefy występują największe kontrasty i dysproporcje wynikające z gęstości, wieku i różnorodności zabudowy, bardzo wysokiej gęstości zaludnienia oraz wielofunkcjonalności. Mają one charakter zarówno przestrzenny (np. konflikt funkcji, dekapitalizacja infrastruktury technicznej i zabudowy), jak i społeczny (np. dysproporcje warunków życia, w tym warunków mieszkaniowych, zróżnicowanie społeczne, patologia) i stanowią najważniejsze problemy do rozwiązywania przez rady osiedlowe.

\subsection{Czynniki społeczne warunkujące oddziaływanie rad osiedlowych na przestrzeń miasta}

3.4.1. Członkowie rad osiedlowych ich cechy społeczne,

Członkowie rad osiedli, ich cechy psychoosobowe, społeczne, doświadczenie, aktywność, relacje z władzami gminy i mieszkańcami oraz umocowanie społeczno-polityczne, stanowią kluczowy element całości systemu jednostek pomocniczych miasta (Matczak 2008). Są oni reprezentantami mieszkańców i gwarantem działań, mających na celu zaspokojenie ich potrzeb. Rady osiedlowe są tworami społecznymi wybieranymi w sposób demokratyczny w wyborach bezpośrednich.

Kadencja członków rady osiedla trwa cztery lata, licząc od dnia wyboru i upływa wraz z kadencją Rady Miejskiej w Łodzi. Wybory do rad są powszechne, równe, bezpośrednie i odbywają się w głosowaniu tajnym, w którym można głosować tylko osobiście i tylko jeden raz. Prawo wybierania (czynne prawo wyborcze) do danej rady ma każdy obywatel, któremu w dniu wyborów przysługuje prawo wybierania do Rady Miejskiej w Łodzi i który stale zamieszkuje na obszarze danej jednostki pomocniczej. W wyborach roku 2005 do podziału było 621 mandatów, natomiast w 2010 r. liczba ta zwiększyła się do 636, w związku z powołaniem nowej 36 jednostki pomocniczej. Liczba osób wchodzących w skład rady uzależniona jest od liczby mieszkańców danego osiedla i w obu kadencjach wynosiła 15 lub 21 członków. W bieżącej kadencji w 20 jednostkach pomocniczych liczba ta wynosi 15 członków a w pozostałych 16 z 21 członków. Spośród wybranych do rady osób wyłaniany jest przewodniczący, zastępca przewodniczącego, sekretarz i skarbnik (Uchwała nr XXXIV/755/2000 Rady Miejskiej w Łodzi z dnia 5 kwietnia 2000 r.). W założeniach, poza osobami funkcyjnymi, każdy radny osiedlowy powinien być aktywnym członkiem, co wiąże się z dobrowolnością decyzji o kandydowaniu. Powin- 
nością radnych jest dbanie o interes całej jednostki osiedlowej, którą reprezentują, oraz wykazywanie gotowości do działań na rzecz jej dobra, a nie o interesy partykularne. Istotne są tutaj predyspozycje poszczególnych osób do pełnienia funkcji społecznych oraz motywy, które popychają osoby do działań na rzecz wspólnego dobra, tym bardziej że ich działalność ma charakter społeczny (radni osiedlowi otrzymują minimalne diety). Tylko takie postawy członków rady wpływają na ewentualne zmiany dysproporcji w wartościach przestrzeni osiedlowych, mogą być odbierane przez mieszkańców jako działania dobre i korzystne dla wszystkich.

Praktyka dowodzi, że członków zaangażowanych w pracę jest na ogół mniej niż wybranych radnych. Poziom aktywności radnych osiedlowych, wyrażający się w działaniu, okazał się zróżnicowany. Część z nich, to osoby praktycznie nie biorące udziału w pracach oraz rzadko bywające na spotkaniach rad. Siłę napędową funkcjonowania rad stanowią działacze aktywni, mobilizujący do pracy innych. Radni mają do dyspozycji pewne zasoby: własne - czas osobisty i umiejętności, formalne - wynikające ze statutu i uchwał rady miasta, materialne - środki finansowe określone przez radę miasta, organizacyjne - pomoc odpowiednich wydziałów urzędu miasta i jego agend, innych partnerów instytucjonalnych działających na tym samym terenie, oraz społeczne - zdolności mobilizacyjne mieszkańców, wyrażające się ich aktywnością. Alokacja części zasobów dokonywana jest za pomocą mechanizmów instytucjonalnych, co zwrotnie wpływa na dobrobyt i potrzeby mieszkańców.

Badania szczegółowe pokazują kim są członkowie rad osiedli oraz czym się zajmują w życiu codziennym, a więc jakie są ich ogólne predyspozycje do działalności społecznej. Radni osiedlowi, w zależności od jednostki osiedlowej, charakteryzują się zróżnicowanym wiekiem, przeważają jednak osoby z przedziału wiekowego 45-70 lat, wśród których znaczną część stanowią emeryci (np. na osiedlach Zdrowie-Mania, Ruda). Zdecydowana większość działaczy ma ustabilizowaną już sytuację rodzinną i status ekonomiczny, dysponuje większymi zasobami czasu wolnego (zwłaszcza emeryci). Udział $w$ radach osiedlowych ludzi młodych jest znacznie mniejszy, co spowodowane jest większym ich zaangażowaniem w kariery zawodowe i organizację własnego życia rodzinnego, ale - co należy podkreślić - ogólnie też niskim zainteresowaniem rozwiązywaniem problemów wspólnotowych. Radni osiedlowi zgłaszają potrzebę udziału osób młodych w swoich strukturach organizacyjnych. Uważają, że ludzie młodzi mogą zwrócić uwagę na istotne problemy, które w rutynowych działaniach starszych są pomijane oraz wnieść do rad osiedlowych nowe formy działalności. Udział osób młodych jest nieco większy w osiedlach blokowych, takich jak np. Teofilów-Wielkopolska, Chojny Dąbrowa czy 
Bałuty-Centrum w porównaniu z osiedlami blokowymi czy jednorodzinnymi z okresu międzywojennego (np. im. Montwiłła Mireckiego, Ruda, Julianów-Marysin-Rogi).

Wśród wszystkich wybranych radnych przeważają mężczyźni (66\% członków rad), ale w 14 jednostkach kobiety stanowią tyko około 1/3 członków rady (np. Łagiewniki, Julianów-Marysin-Rogi, Chojny-Dabrowa, Ruda, Nad Nerem, Koziny). Z drugiej strony w ośmiu jednostkach osiedlowych liczba kobiet jest wyraźnie wyższa niż mężczyzn (np. Zarzew, Montwiłła-Mireckiego, Stare Polesie), lub niemal równa (np. Bałuty-Doły, Radogoszcz, Lublinek-Pienista). Kobiety, w stosunku do ich reprezentacji (w około 30\% rad), rzadziej jednak pełnią funkcję przewodniczących rad osiedlowych.

Działaczami rad osiedlowych są osoby wykonujące różne profesje, w większości przypadków są to zawody wymagające średniego lub wyższego wykształcenia. Dominuje wykształcenie wyższe i średnie, ale w grupie młodych działaczy wiele osób jest jeszcze w trakcie pobierania nauki. Analiza zatrudnienia wskazuje, że najliczniejszą grupę pracujących stanowią zatrudnieni w usługach. Radni są osobami pełniącymi rozmaite funkcje głównie w: szkołach, różnych urzędach na terenie miasta, sądach, ubezpieczeniach i handlu. Znaczną część działaczy stanowią emeryci lub renciści a także osoby prowadzące własną działalność gospodarczą.

Z badań prowadzonych w 2009 r. wynika, że już wówczas w radach osiedlowych część działaczy należała do różnych partii politycznych, ale stopień upartyjnienie był jeszcze nieduży. Okazało się wówczas, że tylko na osiedlu im. Montwiłła Mireckiego nikt nie należał do partii politycznej. W przypadku pozostałych cztery zbadanych jednostek wyglądało to następująco: Chojny - Dąbrowa 4 osoby ( PIS - 1, PO - 2, SLD - 1), Radogoszcz 4 osoby (PO - 1, Prawica RP -1 , SLD - 2), Stoki 3 osoby (SLD - 3), Śródmieście Wschód 1 osoba (PIS).

$\mathrm{Z}$ ankiet przeprowadzonych z 14 przewodniczącymi rad osiedlowych w roku 2013 wynika, że ponad 71\% osób pełni tę funkcję więcej niż dwie kadencje oraz, że są to osoby doświadczone pracujący wcześniej na różnych szczeblach administracji samorządowej, spółdzielczej, agencji rządowych lub administracji gospodarczej. Podsumowując, można stwierdzić, że znaczną część działaczy rad osiedlowych stanowią ludzie z doświadczeniem administracyjno-partyjnym, którzy - również i z racji wieku - przyzwyczajeni są do sposobu działania i postawy charakterystycznej dla czasów minionych.

Wśród motywów, którymi kierowali się aktualni przewodniczący rad podejmując pracę $w$ radach osiedlowych, podawali oni najczęściej takie przyczyny, jak chęć współpracy z radami miasta, namowę kolegów czy też zagospodarowanie wolnego czasu. Ważnymi motywami była również 
potrzeba załatwienia jakiejś sprawy (interes osobisty lub grupowy) oraz wcześniejsza aktywność organizacyjna i duch społecznika, czyli niesienie pomocy innym.

Praca w radach osiedlowych wymaga poświęcenia własnego czasu wolnego i odbywa się kosztem rodziny i pracy zawodowej. Większość ankietowanych stwierdza, że działalność wymaga dużo czasu, który nie da się jednoznacznie określić, ale potrzeba na nią kilka godzin dziennie. W konsekwencji połowa przewodniczących stwierdziła, że ich działalność przeszkadza życiu rodzinnemu a także pracy zawodowej. Osoby, które nie zgłaszały takich problemów najczęściej nie pracowały (emeryci, renciści), prowadziły własną działalność gospodarczą i nie miały rodziny.

Mimo szeregu niedogodności, które wiążą się z działalnością w radach przynosi ona jakieś, najczęściej niewymierne, korzyści. Zgodnie ze statutem miasta Łodzi radni otrzymują diety w wysokości 138 zł miesięcznie, które trudno uznać za dochód adekwatny do wkładu pracy. Dlatego też większość respondentów wskazuje, że osobistych korzyści nie ma żadnych, a często wprost przeciwnie, spotykają ich przykrości ze strony niezadowolonych mieszkańców osiedli. Część z badanych wymienia jednak pewne zyski, takie jak satysfakcja $\mathrm{z}$ rozwiązanych $\mathrm{w}$ osiedlu problemów, poszanowanie innych ludzi, kontakty i znajomości z osobami znaczącymi, możliwość załatwienia spraw inwestycyjnych, którymi często są także osobiście zainteresowani i inne.

Większości badanych przewodniczących rad podkreśla, że współpraca z pozostałymi radnymi układa się bardzo dobrze i dobrze, część mówi o relacjach średnich a nawet i złych, podkreślając trudności z zebraniem wszystkich, bierność oraz zaznaczające się różnice wynikające z przynależności partyjnej.

3.4.2. Relacje rad osiedlowych z władzami miasta, instytucjami i mieszkańcami osiedli

Funkcjonowanie rad osiedlowych i ich skuteczne zaspakajanie potrzeb mieszkańców oraz działania zmieniające na lepsze przestrzeń osiedlową, zależą nie tylko od cech psychofizycznych radnych, ale także od form organizacji pracy rady osiedlowej i sposobów kontaktowania się radnych z mieszkańcami, współpracy z urzędem miasta i instytucjami działającymi na terenie jednostki pomocniczej.

Działania rad osiedlowych ustalane są na zebraniach wszystkich członków, które poświęcone są ustaleniu bieżących spraw wymagających załatwienia. Częstotliwość spotkań w poszczególnych jednostkach była różna, ale w większości (57\% badanych rad) spotykania odbywają się raz w miesiącu. Radni trzech rad osiedlowych spotykają się nawet raz w tygo- 
dniu (Wiskitno, Bałuty centrum, Zdrowie-Mania) a na Górniaku, jak stwierdził przewodniczący, w zależności od potrzeb. Zadania, które rady mają do zrealizowania najczęściej wykonywane są przez organ statutowy jakim jest zarząd (w 5 jednostkach), albo przez powołane komisje lub doraźnie utworzone zespoły (w 5 jednostkach). W pozostałych przypadkach rozwiązywanie zadań było wspólnym działaniem radnych lub zgłaszających się radnych (np. w jednostce Bałuty Doły, czy Osiedle 33).

Jednostki pomocnicze nie są samodzielnymi podmiotami i funkcjonują na podstawie nadrzędnego dla nich statutu gminy. Współpraca jednostek pomocniczych samorządu gminnego, jeśli zostały już powołane, z urzędem miasta i jego agendami ma zatem charakter ustawowy i jest decydująca o skuteczności działania rad osiedlowych. Ocena tej współpracy, dokonana przez przewodniczących rad osiedlowych, stanowi świadectwo postrzegania jednostek pomocniczych przez Radę Miasta Łodzi i Prezydenta. Zaledwie dwie jednostki osiedlowe, na 14 badanych, oceniło tę współpracę jako dobrą i bardzo dobrą (Julianów-Marysin-Rogi i Bałuty Doły - przewodnicząca jest również członkiem Rady Miasta), dwie jako średnią (Wiskitno, Bałuty Centrum), natomiast pozostałe dziesięć jako złą. Zamienne jest, że poza Bałutami Centrum i Bałutami Doły oceny pozytywne wystawiły jednostki pod względem liczby ludności nieduże i położone peryferycznie. Ocena słowna tej współpracy jest miażdżąca dla Urzędu Miasta Łodzi i Prezydenta, o czym świadczą następujące wypowiedzi przewodniczących rad: „najchętniej by się nas pozbyto, jesteśmy piątym kołem u wozu”, „jesteśmy marginalizowani”, „partie i władze gminy zainteresowane sq nie tylko marginalizacja samorządów lokalnych, ale wręcz ich likwidacja”" „jeśli ktoś coś powie co nie podoba się decydentowi to dla osiedla nie będzie pieniędzy", „niekompetencja urzędników”, „w takim stanie jak teraz rady nie mają sensu bycia”, „współpraca nie idzie w dobrym kierunku, widzę to bardzo źle”, „to jest spychotechnika $w$ Urzędzie miasta, to się nasiliło w ostatniej kadencji". W świetle tych wypowiedzi można stwierdzić, że ogólny sens istnienia lokalnego samorządu terytorialnego jest przez gminę kwestionowany. Utrudnianie jego działania przez brak pomocy, ograniczenia finansowe, nieliczenie się ze zdaniem samorządów i traktowanie ich jako zła koniecznego, narusza fundament systemu demokratycznego i prowadzi do znanego z niedalekiej przeszłości centralizmu demokratycznego. Rola i prestiż samorządu lokalnego wśród mieszkańców jednostek osiedlowych systematycznie maleje, zarazem narasta rozczarowanie, i tak już nielicznych, działaczy społecznych.

Rady osiedlowe współpracują efektywnie z pewnymi instytucjami zlokalizowanymi i działającymi na terenie jednostek. Wszystkie badane rady osiedlowe współpracują z instytucjami oświatowo-kulturalnymi i opieki społecznej (szkoły, domy kultury, domy opieki społecznej, itp.), pomagając 
im głównie w zakresie inwestycyjnym, z drugiej strony instytucje te wspierają rady osiedlowe w zakresie organizacyjnym (uroczystości, święta, konkursy, itp.). Intensywne relacje łączą również rady z parafiami katolickimi (64\% rad), ze strażą pożarną i miejską policją ( $57 \% \mathrm{rad})$, sąsiednimi radami osiedlowymi (57\% rad) oraz z innymi instytucjami i zrzeszeniami, wśród których wyróżnia się współpraca z kołami gospodyń wiejskich, zwłaszcza na obszarach, gdzie poprzednio funkcjonowały sołectwa (Nowosolna, Mileszki, Wiskitno).

Poza kontaktami i współpracą z różnymi instytucjami i organizacjami, najważniejsze relacje powinny łączyć rady osiedlowe z właściwym podmiotem i głównym sensem istnienia samorządu lokalnego jakimi są mieszkańcy jednostek pomocniczych. Z ogółu respondentów 65\% oceniło stopień współpracy pomiędzy mieszkańcami a przedstawicielami rady osiedla jako niski, a 35\% jako średni. Żadna z badanych osób nie stwierdziła, że jest on wysoki. Relacje te są uwarunkowane dwustronnie, tzn. zależą od aktywności społecznej samych mieszkańców oraz od sprawności działania rad osiedlowych i utrzymywania ścisłego kontaktu z mieszkańcami osiedli.

Badania wykazały, że kontakty członków rad osiedlowych z mieszkańcami przyjmują głównie formy tradycyjne. Polegają one na spotkaniach $\mathrm{w}$ trakcie organizowania i trwania różnych imprez organizowanych przez radę osiedlową, kontaktach członków rady ze swoimi sąsiadami i na ulicy (86\% odpowiedzi przewodniczących rad) oraz w trakcie trwania obligatoryjnych dyżurów członków rad (77\%). Poza tym informacje o ważnych dla mieszkańców sprawach zamieszczane są na plakatach i ogłoszeniach. Niewiele rad osiedlowych korzysta z przekazu internetowego (Wiskitno i Julianów-Marysin-Rogi), a w jednej jednostce pomocniczej wydawany był biuletyn informacyjny (Zdrowie-Mania). Opinia mieszkańców pytanych o najlepsze formy kontaktowania się rady ze społecznością lokalną jest bardzo zróżnicowana i nie daje odpowiedzi na to, które z nich są najbardziej odpowiednie. Najwięcej wypowiedzi (24\%) dotyczyło ogłoszeń wywieszanych na tablicy, $16 \%$ odpowiedzi wskazywało na informacje wysyłane drogą elektroniczną, $15 \%$ - na gazetki osiedlowe, $10 \%$ - listy, $9 \%$ - informacje przekazywane osobiście, $8 \%$ - na organizowanie cyklicznych spotkań z mieszkańcami. Pozostałe pomysły odnosiły się do rozwieszania plakatów informujących o działaniach rady, rozdawania ulotek, kontaktu telefonicznego, posiadania strony internetowej oraz podawania wiadomości w lokalnych mediach.

Problem słabych relacji i kontaktów z mieszkańcami oraz braku ich wiedzy o osiągnięciach i działaniach samorządu lokalnego nie tkwi w złych, czy tradycyjnych formach kontaktów, a ma inne przyczyny związane z samymi społecznościami lokalnymi i funkcjonowaniem radami osiedlowych. 


\subsubsection{Aktywność mieszkańców jednostek pomocniczych}

Ważnym czynnikiem wpływającym na funkcjonowanie jednostek pomocniczych samorządu terytorialnego jest aktywność społeczna mieszkańców, ona to bowiem gwarantuje wybranie do rad osiedlowych osób możliwie najlepszych, tj. uczciwych, cieszących się zaufaniem miejscowej społeczności, chcących pracować na rzecz terytorialnego dobra wspólnego. Na aktywność społeczną mieszkańców ma wpływ wiele czynników, w tym wiedza o ewentualnym przedmiocie aktywności i przekonanie, że takie działanie ma sens i przynosi oczekiwane rezultaty.

W celu uzyskania informacji obrazujących wiedzę mieszkańców Łodzi o radach osiedli, przeprowadzono w 2009 r. wywiady kwestionariuszowe w wybranych do badań pięciu jednostkach pomocniczych. Punktem wyjścia było zorientowanie się, czy mieszkańcy kiedykolwiek słyszeli o radach osiedla i czy mają świadomość, że one funkcjonują w miejscu ich zamieszkania. Okazało się, że znaczny odsetek respondentów słyszał o radach osiedla (78\%). Wiedza ta była $100 \%$ w małych jednostkach osiedlowych (im. Montwiłła Mireckiego i na Stokach) natomiast w dużych i gęsto zaludnionych, część osób nigdy o nich nie słyszała. Sposób podziału miasta na jednostki osiedlowe ma zatem istotny wpływ na zainteresowanie nimi mieszkańców.

Kolejnym czynnikiem mogącym mieć wpływ na aktywność społeczną mieszkańców jest ich wiedza na temat tego, czym zajmuje się rada osiedla. Uzyskane odpowiedzi na ten temat podzielono na: prawidłowe, częściowo prawidłowe, nieprawidłowe oraz typu „nie wiem”. Największa liczba osób (39) określiła dość dokładnie, czym zajmuje się rada osiedla, a znaczna część (25 osób) miała o tym ogólne pojęcie, pozostali respondenci udzielili odpowiedzi błędnych lub nic na ten temat nie wiedzieli.

Zainteresowanie działaniami rad osiedlowych, nawet wśród tych, którzy kiedykolwiek o nich słyszeli, jest generalnie słabe i bardzo słabe (łącznie 81\% respondentów). Zdecydowana większość respondentów (79\%) zadeklarowała, że nie brała udziału w pracach na rzecz osiedla. Mieszkańcy, jako powód nieuczestniczenia w pracach na rzecz osiedla podawali $\mathrm{w}$ $90 \%$ braku czasu. Na brak zainteresowania działalnością społeczną oraz niski poziom zaufania do ludzi będących członkami rady osiedla wskazywały nieliczne osoby.

Niewielka wiedza respondentów oraz brak większego zainteresowania działaniem rad znajdują swoje potwierdzenie w braku znajomości członków własnej rady osiedlowej (87\% ogółu badanych nie wiedziało kto zasiada $w$ tej radzie). Zadziwiające jest, że respondenci nie byli zainteresowani funkcjonowaniem najniższego szczebla samorządu terytorialnego i ludźmi zajmującym się z mocy prawa problemami im najbliższymi, na które mogą mieć wpływ realny. 
Większość mieszkańców badanych jednostek (54\%) uważała, że ma mały wpływ na decyzje rady osiedla, wpływ ten był zauważalny tylko dla niewielkiej części respondentów (22\%), natomiast 12\% stwierdziło, że nie ma na nie żadnego wpływu. Badania pokazały bardzo niski poziom zaangażowania społecznego oraz gotowości mieszkańców do uczestnictwa w działaniach na rzecz osiedla (27\% respondentów. Powodów takiego stanu rzeczy można się dopatrywać w braku wzorców motywujących społeczności do zbiorowych działań, braku liderów oraz małych możliwości, a co za tym idzie niskiej efektywności działania. Badania wykazały również, że im bardziej mieszkańcy identyfikowali się ze swoim otoczeniem - osiedlem na którym mieszkają, tym większą wykazywali aktywność lokalną i zainteresowanie tym, co się wokół dzieje. Problem wzmacnia zatem fakt przypadkowego (na zasadach sąsiedztwa) połączenia w jednostki pomocnicze różnych funkcjonalnie, morfologicznie i społecznie obszarów, co nie sprzyja identyfikacji terytorialnej, która jest jednym z motywów do działań lokalnych. Przyczynia się to, obok innych przyczyn społecznych, do uruchomienia mechanizmu działania partykularnego, a nie wspólnotowego, co oznacza załatwianie spraw, które leżą w kręgu bezpośredniego zainteresowania najbardziej aktywnych działaczy rady (według schematu myślowego: poświęcam swój czas, więc mi się z tego tytułu należy w pierwszej kolejności). Świadomość tego wśród mieszkańców wzmacnia z kolei stereotyp myślenia: działają dla własnych interesów i zasłaniają się dobrem wspólnym, mają z tego jakieś korzyści, mnie to nie interesuje i nie mam na to czasu itp. Stwarza to sytuację, w której idea samorządu terytorialnego traci swoją moc budowania społeczeństwa obywatelskiego i prowadzi przez atomizację do rozpadu istniejących jeszcze terytorialnych struktur społecznych (np. na peryferii Łodzi działających do niedawna silnych wspólnot sołeckich). Procesy te wzmacniają centralistyczne formy zarządzania, z czym wiąże się brak kontroli społecznej celowości wydatkowanych pieniędzy, w których o wszystkim decyduje władza miasta. W konsekwencji prowadzi także do społecznej bierności, zaniku myślenia wspólnotowego o naszym miejscu życia i umacnianiu się przekonania, że moje jest najważniejsze a w dodatku trzeba je wywalczyć za każdą cenę, najlepiej za cenę dobra wspólnego. W efekcie skutkuje to złym zarządzaniem i gospodarowaniem przestrzenią miejską, marnotrawstwem sił i środków, chaosem urbanistycznym, bylejakością i brzydotą form zagospodarowania oraz pogłębianiem dysproporcji społecznych i przestrzennych.

Najogólniejszym wskaźnikiem aktywności mieszkańców jest ich uczestnictwo w wyborach do rad osiedlowych a więc do jednostek administracji samorządowej, która ma bezpośredni wpływ na rozwiazywanie problemów ludzi w miejscu ich zamieszkania, na wygląd i dostosowanie prze- 
strzeń lokalnej do potrzeb jej użytkowników, wreszcie na kształtowanie się postaw wspólnotowych w osiedlu.

Wybory ostatnie (2010 r.) wskazują na bardzo niską aktywność społeczną mieszkańców jednostek osiedlowych. Ogólna frekwencja w mieście była niska i wyniosła 13,1\%, a w niektórych osiedlach nawet mniej niż $10 \%$ osiągając swoje minimum na Starym Polesiu - 4,4\%. Maksymalna frekwencja niewiele przekraczała $20 \%$ i to tylko w dwóch mało ludnych (poniżej 2 tys. mieszkańców) jednostkach: Dolina Łódki - 24,9\% i Nad Nerem - 22,4\% (ryc. 3.3 ).

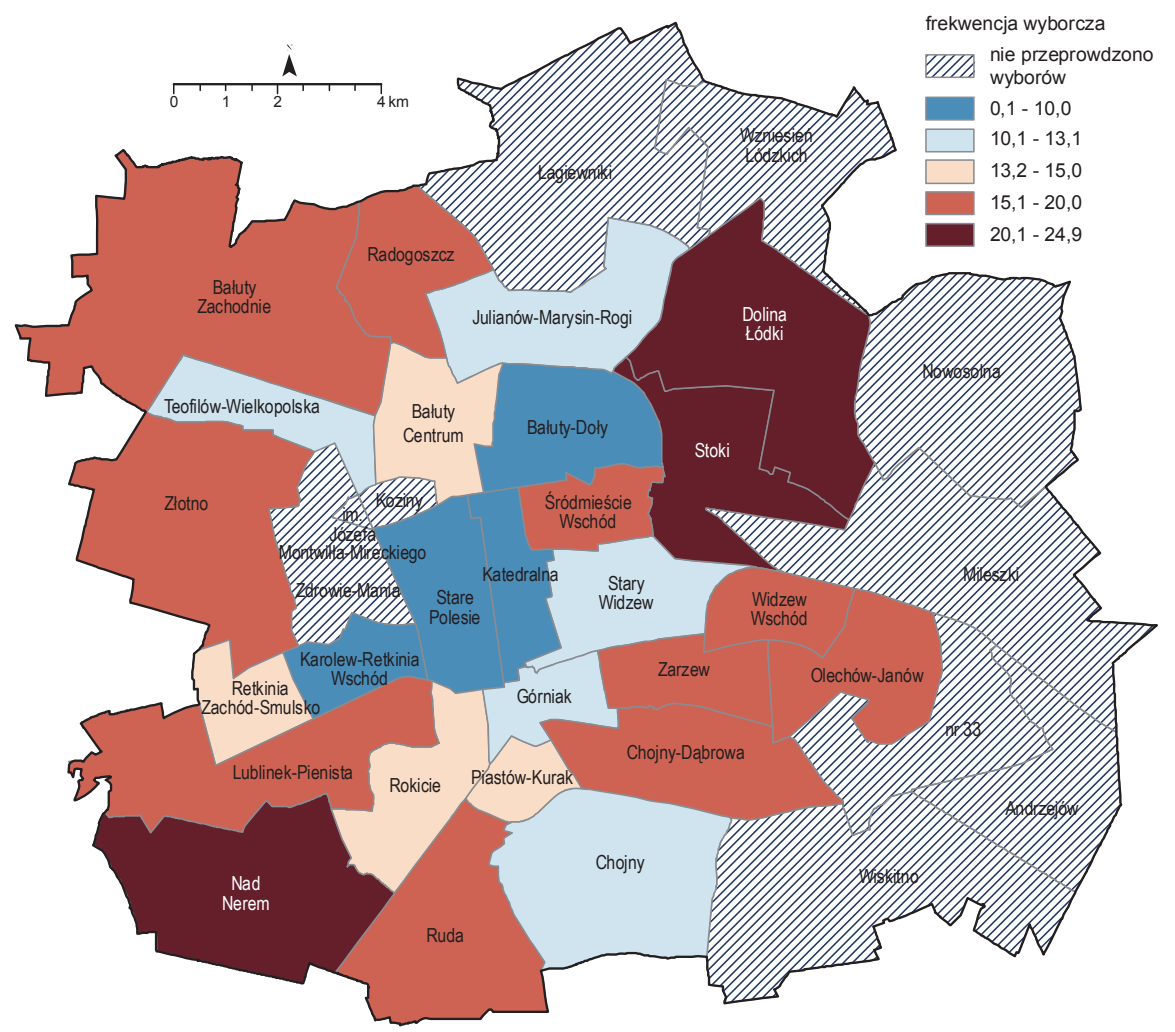

Ryc. 3.3. Frekwencja wyborcza w wyborach do rad osiedlowych w Łodzi w 2010 roku Źródło: opracowanie własne na podstawie danych PKW

Generalnie niski poziom frekwencji wyborczej w wyborach do rad osiedli jest też efektem niskiej atrakcyjności wyborów - z punktu widzenia poszczególnych mieszkańców. Potwierdza to odpowiedź na pytanie "Co właściwie mogę osiągnąć głosując, czego nie mógłbym osiągnąć nie głosując?” brzmiąca najczęściej: „nic”, lub „bardzo niewiele”.

Wpływ na wysokość frekwencji wyborczej miało również zachowanie przedstawicieli władz miejskich, Komisarza Wyborczego oraz Dyrektora 
Delegatury Krajowego Biura Wyborczego w Łodzi, którzy żądali od członków obwodowych komisji wyborczych do rady Miejskiej w Łodzi, aby nie informowali wyborców o usytuowaniu lokali obwodowych komisji wyborczych przeprowadzających wybory do rad osiedli, które nota bene znajdowały się w tych samych budynkach. Tę kuriozalną sytuację, która może świadczyć o negatywnym stosunku do istnienia samorządów lokalnych w mieście (patrz cytowane wcześniej wypowiedzi przewodniczących rad osiedlowych), potwierdzają liczne interwencje mieszkańców Łodzi biorących udział w wyborach do rad osiedli poszukujących lokali wyborczych.

Porównanie podstawowych charakterystyk dwóch ostatnich wyborów, które odbyły się w roku 2005 i 2010 (tabela 3.2), pokazuje jednoznacznie na spadek i tak już niskiej aktywności wyborczej, jak i zaangażowania mieszkańców Łodzi w działalność na rzecz wspólnot terytorialnych. Przejawem wzrostu bierności społecznej wśród mieszkańców jest zarówno zmniejszenie liczby list zgłoszonych do wyborów, której wartość spadła o blisko $45 \%$, jak i - przede wszystkim - liczby osób chętnych do pracy w radach osiedlowych o ponad $47 \%$ (liczba osób zgłoszonych). Dotyczy to właściwie wszystkich jednostek osiedlowych z wyjątkiem Rudy, gdzie liczba list była o jedną większa, ale liczba kandydatów na te listy spadła, a także jednostki Nad Nerem, w której liczba list była taka sama, a liczba osób kandydujących wzrosła.

Tabela 3.2

Charakterystyka wyborów w 2005 i 2010 roku

\begin{tabular}{|l|c|c|}
\hline \multirow{2}{*}{\multicolumn{1}{|c|}{ Wskaźnik }} & \multicolumn{2}{c|}{ Rok wyborów } \\
\cline { 2 - 3 } & 2005 & 2010 \\
\hline Liczba jednostek pomocniczych & 35 & 36 \\
\hline Liczba list wyborczych & 244 & 134 \\
\hline Liczba list na jeden okręg wyborczy & 6,9 & 3,7 \\
\hline Liczba kandydatów na członków do rad & 2265 & 1071 \\
\hline Liczba kandydatów na jeden okręg wyborczy & 64,7 & 29,7 \\
\hline Liczba kandydatów na jeden mandat wyborczy & 3,6 & 1,7 \\
\hline
\end{tabular}

Źródło: opracowanie własne na podstawie: Informacja Miejskiej Komisji Wyborczej o zgłoszonych listach kandydatów do rad jednostek pomocniczych Miasta - rad osiedli w wyborach zarządzonych na dzień 6 marca 2005 r. oraz Informacja o liczbie ważnie oddanych głosów i o frekwencji wyborczej w wyborach rad jednostek pomocniczych Miasta - rad osiedli zarządzonych na dzień 21 listopada 2010 r.

W wielu osiedlach, w stosunku do 2005 r., odsetek chętnych do działania w radach spadł o ponad 2/3 (np. Stare Polesie - 77\%, Katedralna $76 \%$, Chojny - 68\%, Retkinia-Smulsko - 65\%). W roku 2005 tylko w jednym osiedlu - nr 25 (dzisiaj Nad Nerem) nie przeprowadzono wyborów, ponieważ ogólna liczba kandydatów była równa liczbie przewidzianych 
dla tego osiedla mandatów i za wybranych uznani zostali zgłoszeni kandydaci. W pięć lata później wyborów z tego powodu nie przeprowadzono aż w 10 osiedlach i postąpiono podobnie jak w wyborach poprzednich, uznając zgłoszonych za wybranych (Łagiewniki, Wzniesień Łódzkich, Wiskitno, Zdrowie-Mania, Koziny, im. J. Montwiłła-Mireckiego, Nowosolna, Mileszki, Andrzejów i Nr 33).

Ocena aktywności mieszkańców na rzecz jednostek pomocniczych, dokonana przez przewodniczących rad osiedlowych, potwierdza ich niskie zaangażowanie $w$ problemy lokalne. Respondenci uznali, że w sześciu jednostkach jest ona dobra, ale w pozostałych ośmiu określono, że jej brak lub jest średnia i związana ściśle z załatwianiem indywidualnego interesu.

Równocześnie przewodniczący pytani o to, czy mieszkańcy pomagają w pracach rady osiedla w 10 przypadkach stwierdzili, że nie, czasami lub przez instytucje, a tylko w 4 , że pomoc taką otrzymują.

Zdaniem przewodniczących, dokonywana przez mieszkańców ocena działalności rad osiedlowych, jest raczej dobra (10 wypowiedzi dających oceny bardzo dobra, średnia i pozytywna, wobec tylko 4 określających ją jako różną). Należy wziąć pod uwagę, że formułowanie przez przewodniczących oceny negatywnej jest, w pewnym stopniu, wystawieniem złego świadectwa własnej działalności, a więc ich liczba może być zaniżona.

\subsection{Formy i efekty społecznej i przestrzennej działalności rad osie- dlowych - przykłady empiryczne}

3.5.1. Uwarunkowania finansowe możliwości oddziaływani rad osiedli na lepsze zaspokojenie potrzeb mieszkańców.

Rada osiedla jest formą organizacyjną miasta, która pociąga za sobą pewne koszty - mierzone wydatkami budżetu miasta, ale także wysiłkiem i zaangażowaniem mieszkańców. Nasuwa się pytanie, czy są to wydatki uzasadnione korzyściami, jakie przynoszą te jednostki, tzn. czy zmieniają one pozytywnie przestrzeń fizyczną i przyczyniają się do budowy wspólnot osiedlowych?

Jednostka pomocnicza prowadzi gospodarkę finansową w ramach budżetu miasta na podstawie zatwierdzonego przez Prezydenta Miasta Łodzi planu finansowego. Corocznie w budżecie miasta tworzona jest rezerwa celowa, w kwocie nie niższej od 10000000 zł, przeznaczona na realizację lokalnych zadań inwestycyjnych lub remontowych zgłoszonych przez jednostki pomocnicze Łodzi. Środki te są dzielone na połowę: pierwsza część rezerwy celowej przeznaczona jest na finansowanie drobnych, niewymagających dłuższych przygotowań zadań inwestycyjnych lub remontowych wskazanych przez osiedla w trybie tzw. algorytmu 3, natomiast druga - na realizację zadań inwestycyjnych wyłanianych w drodze corocz- 
nie przeprowadzanego konkursu. Koszty realizacji zgłoszonego do konkursu zadania inwestycyjnego (wraz z dokumentacją projektową, jeśli jej brakuje) nie mogą być mniejsze niż 100000 zł i większe niż 1000000 zł. Na działalność statutową każda rada osiedla otrzymuje 20000 zł + 1,50 zł na każdego mieszkańca danej jednostki pomocniczej.

Rady osiedli mają do rozdysponowania środki finansowe, które mogą być przeznaczone na projekty inwestycji, dofinansowanie już prowadzonych i tworzenie nowych. $\mathrm{Z}$ reguły jest to suma nie wystarczająca na wszystkie pomysły i potrzeby jednostek osiedlowych. Ponadto, istnieje możliwość uzyskania dodatkowych funduszy na realizację zadań inwestycyjnych wyłanianych w drodze corocznie przeprowadzanego konkursu. Przedmiotem konkursu są jednoroczne zadania inwestycyjne zgłaszane przez poszczególne jednostki bądź wspólnie przez kilka z nich (www.bip. uml.lodz.pl). Zadania te mogą obejmować w szczególności: budowę, modernizację lokalnych dróg, chodników i oświetlenia, budowę, modernizację w zakresie małej infrastruktury technicznej, budowę lub modernizację osiedlowych placów zabaw i urządzeń kultury fizycznej, poprawę bezpieczeństwa mieszkańców, tworzenie zieleńców i skwerów wraz z małą architekturą.

Pierwsza edycja konkursu odbyła się w 2005 r., jednak żadna z propozycji przedstawionych wówczas przez badane osiedla nie została uznana przez Komisję Konkursową. Rok później osiedle Stoki otrzymało 290000 zł na modernizację zieleńca przy ulicy Junackiej, a Zdrowie-Mania wraz z osiedlem im. Józefa Montwiłła-Mireckiego - 550576 zł na budowę odcinka ulicy Chłopickiego. W 2007 r. jednostce Stoki przyznano 505715 zł na modernizację ul. Nowogrodzkiej na odcinku od ul. Edwarda do posesji nr 55 oraz 978276 zł wspólnie z Mileszkami i Widzewem Wschód na budowę boiska sportowego zlokalizowanego w Łodzi przy ul. Dębowskiego i ul. Potokowej. W kolejnej edycji konkursu Radogoszcz otrzymał 706802 zł na budowę ulic: Koniczynowej na odcinku od ul. Turzycowej do ul. Szuwarowej oraz Turzycowej na odcinku od ul. Koniczynowej do ul. Kruszynowej. Ponownie już pewną kwotę na zadanie inwestycyjne przyznano osiedlu Stoki: 100209 zł na oświetlenie ul. Kosodrzewiny od nr 1 do nr 36 (z osiedlem Mileszki), 1000000 zł na zagospodarowanie i budowę osiedlowego placu zabaw oraz zespołu boisk osiedlowych wraz z elementami małej architektury w rejonie ulic: ks. Z. Wujaka, F. Dostojewskiego i M. Ćwiklińskiej, na terenie pomiędzy ZSO nr 1 a Szkołą Podstawową $\mathrm{nr}$ 34 i Gimnazjum nr 29 (z osiedlem Nr 33 i Widzewem Wschód) oraz 980000 zł na rozbudowę boiska sportowego zlokalizowanego pomiędzy ul. Dębowskiego, ul. Potokową a ul. Giewont (z osiedlem Mileszki i Nr 33, www.bip.uml.lodz.pl). W 2009 r. ogłoszono V już edycję konkursu, w którym osiedle im. Montwiłła Mireckiego zajęło II miejsce z zabezpie- 
czeniem z UM kwoty 427.700 zł na remont osiedlowej przychodni dla dorosłych na ul. Srebrzyńskiej 75.

Podane przykłady świadczą, że pozyskane w drodze konkursów pieniądze w poważny sposób mogą zmienić zagospodarowanie przestrzeni podnosząc jego standard i estetykę lub wzmocnić funkcjonowanie osiedlowych instytucji publicznych. Forma przyznawania środków w postaci konkursu z jednej strony daje urzędowi miasta pełną kontrolę nad projektowanymi działaniami, z drugiej jest narzędziem silnego podporządkowania rad osiedlowych, ponieważ jak stwierdził jeden z przewodniczących: „jeśli ktoś coś powie co nie podoba się decydentowi to dla osiedla nie będzie pieniędzy". Pamiętać należy, że rada osiedla jest jedynie organem wnioskującym i opiniodawczym, a ostateczną decyzje o finansowaniu zgłaszanych inwestycji podejmuje Urząd Miasta Łodzi. Ogólny rozdział środków na finansowanie Rad Osiedlowych często ulega zmniejszeniu, jeśli w mieście brakuje pieniędzy na inne - ważniejsze, zdaniem rady miasta i prezydenta, zadania gminy.

\subsubsection{Działalność rad osiedlowych i jej efekty przestrzenne i społeczne}

Rady osiedli przez całą swoją kadencję realizują pewne działania, leżące w ich kompetencjach, których zakres omówiono w punkcie 2. Działalność rad osiedlowych, ich konkretne osiągnięcia pokazujące zmiany w przestrzeni fizycznej, najlepiej przybliżyć na konkretnych przykładach. W tabeli 3.3 pokazano sprawy zakończone powodzeniem w poprzedniej kadencji rad w 5 badanych wówczas jednostkach pomocniczych (2005-2010). Zdecydowana większość dotyczy kwestii infrastruktury, gospodarki komunalnej oraz oświaty i wychowania. Sztandarowymi inwestycjami są przede wszystkim nowe chodniki, utwardzanie dróg, nowe asfaltowe nawierzchnie, place zabaw dla dzieci i boiska sportowe. Jak widać wszystkie badane osiedla realizują praktycznie podobne zadania, jedyne różnice mogą się pojawiać w przypadku ich skali i przeznaczanych środków finansowych. Bardzo ważne dla radnych osiedlowych jest także organizowanie dla mieszkańców różnego rodzaju imprez integracyjnych, takich jak: festyny, konkursy, turnieje sportowe, kolacje wigilijne, śniadania wielkanocne itp. 
Tabela 3.3

Przykładowe działania rad osiedli zakończone powodzeniem w kadencji 2005-2010

\begin{tabular}{|c|c|}
\hline Zakres działania & Przykładowe osiągnięcia \\
\hline 1 & 2 \\
\hline \multicolumn{2}{|r|}{ Chojny - Dąbrowa } \\
\hline Transport i łączność & $\begin{array}{l}\text { nowe chodniki i remonty już istniejących, moderniza- } \\
\text { cja infrastruktury drogowej }\end{array}$ \\
\hline Oświata i wychowanie & $\begin{array}{l}\text { współpraca ze szkołami przy organizacji różnych } \\
\text { konkursów i imprez w szkołach i przedszkolach, } \\
\text { zakup pomocy edukacyjnych do szkół podstawowych, } \\
\text { oświetlenie boisk na terenach sportowych szkoły } \\
\text { podstawowej }\end{array}$ \\
\hline $\begin{array}{l}\text { Gospodarka komunalna i ochrona } \\
\text { środowiska }\end{array}$ & $\begin{array}{l}\text { założenie oświetlenia na ul. Jedwabniczej i Transporto- } \\
\text { wej, } \\
\text { budowa placów zabaw oraz zakup zabawek i urządzeń, } \\
\text { inicjatywa zagospodarowania Młynka }\end{array}$ \\
\hline \multicolumn{2}{|c|}{ im. Montwiłła Mireckiego } \\
\hline Transport i łączność & $\begin{array}{l}\text { wykonanie } 9 \text { szt. przejść dla pieszych z kostki bruko- } \\
\text { wej, } \\
\text { wykonanie nowych chodników i doprowadzenie do } \\
\text { stanu używalności już istniejących, przywrócenie } \\
\text { komunikacji autobusu nocnego linii N3 }\end{array}$ \\
\hline Oświata i wychowanie & $\begin{array}{l}\text { stała współpraca z przedszkolem, Szkołą nr 40, } \\
\text { Liceum Ogólnokształcącym nr } 18 \text { - zakup odpowied- } \\
\text { nich pomocy naukowych }\end{array}$ \\
\hline Turystyka & $\begin{array}{l}\text { zorganizowanie i opłacenie wyjazdu integracyjno - } \\
\text { edukacyjnego do Wrocławia na Panoramę Racławicką }\end{array}$ \\
\hline $\begin{array}{l}\text { Gospodarka komunalna i ochrona } \\
\text { środowiska }\end{array}$ & $\begin{array}{l}\text { zainstalowanie na elewacji budynków } 36 \text { szt. lamp } \\
\text { stylizowanych na dawne lampy gazowe, oświetlenie } \\
\text { kładki dla pieszych nad torami, } \\
\text { całkowita renowacja i rekultywacja reprezentacyjnego } \\
\text { skweru na rogu al. Unii Lubelskiej i Srebrzyńskiej }\end{array}$ \\
\hline Kultura fizyczna i sport & $\begin{array}{l}\text { działania dzięki, którym wybudowano ogólnodostęp- } \\
\text { ny kompleks sportowy - Orlik }\end{array}$ \\
\hline \multicolumn{2}{|r|}{ Radogoszcz } \\
\hline Transport i łączność & $\begin{array}{l}\text { budowa ul. Koniczynowej } \\
\text { budowa chodników i miejsc postojowych oraz remon- } \\
\text { ty już istniejących }\end{array}$ \\
\hline
\end{tabular}


Tabela $3.3 \mathrm{~cd}$.

\begin{tabular}{|c|c|}
\hline 1 & 2 \\
\hline Oświata i wychowanie & $\begin{array}{l}\text { budowa ogródka przedszkolnego, zakup i montaż } \\
\text { urządzeń na plac zabaw }\end{array}$ \\
\hline $\begin{array}{l}\text { Gospodarka komunalna i } \\
\text { ochrona środowiska }\end{array}$ & $\begin{array}{l}\text { dofinansowanie wykonania przyłącza wodociągowego } \\
\text { do posesji na ul. Bema, uzupełnienie brakującego } \\
\text { oświetlenia na ul. Studzińskiego, budowa placu zabaw } \\
\text { dla dzieci przy ul. Liściastej oraz zakup urządzeń } \\
\text { i zabawek }\end{array}$ \\
\hline Kultura fizyczna i sport & $\begin{array}{l}\text { budowa bieżni oraz skoczni do skoku w dal, rozbudowa } \\
\text { boiska wielofunkcyjnego w okolicach Alei Uśmiechu }\end{array}$ \\
\hline & Stoki \\
\hline Transport i łączność & modernizacja ul. Nowogrodzkiej - nowe chodniki \\
\hline Oświata i wychowanie & $\begin{array}{l}\text { wymiana okien w przedszkolu, szkole podstawowej } \\
\text { i gimnazjum, } \\
\text { modernizacja boiska szkolnego w Gimnazjum Publicz- } \\
\text { nym, zakup zabawek do Przedszkoli nr 94, nr 93, nr } \\
63, \text { zakup tablic interaktywnych dla gimnazjum }\end{array}$ \\
\hline $\begin{array}{l}\text { Gospodarka komunalna i ochrona } \\
\text { środowiska }\end{array}$ & $\begin{array}{l}\text { wykonanie i montaż urządzeń małej architektury } \\
\text { w parku im. Zaruskiego oraz budowa stałej sceny, } \\
\text { zieleńce na Sikawie, budowa placu zabaw przy ul. } \\
\text { Dębowskiego }\end{array}$ \\
\hline Kultura fizyczna i sport & $\begin{array}{l}\text { budowa boiska sportowego przy ul. Dębowskiego - } \\
\text { Potokowej }\end{array}$ \\
\hline \multicolumn{2}{|r|}{ Śródmieście Wschód } \\
\hline Transport i łączność & $\begin{array}{l}\text { nowe chodniki i remonty istniejących, naprawa } 1 \text { drog } \\
\text { gminnej }\end{array}$ \\
\hline Oświata i wychowanie & $\begin{array}{l}\text { częściowe remonty przedszkoli, wyposażenie } 6 \\
\text { przedszkoli w infrastrukturę placów zabaw, ogrodze- } \\
\text { nie wielu szkół, wymiana okien w salach gimnastycz- } \\
\text { nych } 2 \text { szkół, utworzenie salki teatralnej w } 1 \text { Szkole } \\
\text { Podstawowej }\end{array}$ \\
\hline $\begin{array}{l}\text { Gospodarka komunalna i ochrona } \\
\text { środowiska }\end{array}$ & $\begin{array}{l}\text { skwer przy ul. Zelwerowicza, skwery wypoczynkowe } \\
\text { na terenach } \\
\text { Wspólnot Mieszkaniowych, budowa i wyposażenie } 2 \\
\text { placów zabaw }\end{array}$ \\
\hline
\end{tabular}

Źródło: D. Weber, 2010.

Badania ankietowe przeprowadzone w 2013 r. (w nowej kadencji rad) potwierdziły zakres działań rad osiedlowych: były to inwestycje (w 13 jednostkach) związane z poprawą infrastruktury technicznej (drogi, chodniki, inwestycje sieciowe), pomoc instytucjom publicznym (szkoły, przedszkola, domy opieki, domy kultury) polegająca na dofinansowaniu remon- 
tów, drobnych inwestycji budowlanych i wyposarzenia w sprzęt, organizacja imprez integracyjnych: pikniki, Wigilia, Dzień Dziecka, Dzień Sąsiada itp. (w 13 jednostkach osiedlowych), turnieje sportowe (w trzech jednostkach). Dzięki imprezom integracyjnym, jak podkreślali respondenci, społeczność osiedli ma możliwość poznania członków rad, a przede wszystkim dowiedzenia się, że taki twór jak rada osiedla w ogóle funkcjonuje. Realizacja zadań przez rady osiedli wiąże się często ze współpracą z innymi organizacjami (przedszkolami, szkołami, parafiami, policją, spółdzielniami mieszkaniowymi), co prowadzi do budowy pewnego rodzaju sieci powiązań lokalnych, które pomagają realizować wiele zadań inwestycyjnych, integrują obszar i mieszkańców oraz zmieniają jego oblicze na korzyść.

Działacze osiedlowi są świadomi swoich sukcesów i porażek, które w dużym stopniu uzależnione są od braku aktywności niektórych członków i nieprzychylnych działań urzędów, dotyczących konkretnych przypadków. Oczekiwania i problemy zgłaszane przez mieszkańców mogą być rozmaite, jednak nie zawsze istnieje możliwość ich realizacji.

Za największe sukcesy poprzedniej kadencji w badanych jednostkach pomocniczych uznano zrealizowanie inwestycji, szczególnie w zakresie infrastruktury oraz rekreacji. Za sukces uznano również współpracę z różnymi podmiotami, aktywność członków i udane imprezy organizowane dla mieszkańców (tabela 3.4).

Przedstawiciele zarządów badanych jednostek byli świadomi niepowodzeń swoich działań wynikających z pracy rady osiedlowej, ale także uwarunkowanych przyczynami zewnętrznymi (Urząd Miasta, instytucje wykonujące prace itp.). Na osiedlach Radogoszcz i Śródmieście Wschód zwrócono uwagę na słabą aktywność członków rady oraz ich niską frekwencję na posiedzeniach rady osiedla. Zdaniem przewodniczącego Rady Osiedla im. Montwiłła Mireckiego wszystko co było zamierzone zostało zrealizowane, a porażką byłoby nieuzyskanie środków pieniężnych na remont Przychodni Miejskiej dla dorosłych. W przypadku pozostałych dwóch jednostek odczucia są podobne. Na osiedlu Chojny-Dąbrowa niepowodzenia dotyczą odrzuconych projektów budowy placów zabaw oraz ścieżek rowerowych od Młynka do Stawów Stefańskiego, na Stokach zaś nieudanych inwestycji blokowanych przez urzędy oraz ciągłych problemów z ul. Edwarda.

W badaniach z roku 2013 tylko w jednej radzie stwierdzono, że wszystkie zadania zostały wykonane. $\mathrm{W}$ dwóch jednostkach za porażkę uznano niewygranie konkursu, w dziewięciu niewykonanie prac związanych z naprawą ulic, drobnych inwestycji i remontów, w czterech nie pozyskanie środków finansowych i w jednej niewykorzystanie, zrobionych za pieniądze rady, projektów technicznych. 
Największe sukcesy rad osiedli w kadencji 2005-2010

\begin{tabular}{|l|l|}
\hline Jednostka pomocnicza & \multicolumn{1}{c|}{ Sukces rady osiedla } \\
\hline Chojny-Dąbrowa & $\begin{array}{l}\text { realizacja budżetu współpraca z podmiotami będącymi } \\
\text { w zasięgu rad: kluby seniora, sportowe, szkoły, przedszkola itp. }\end{array}$ \\
\hline $\begin{array}{l}\text { Mim. Montwiłła- } \\
\text { Mireckiego }\end{array}$ & $\begin{array}{l}\text { odpowiedni dobór członków, dzięki czemu współpraca układa } \\
\text { się bardzo dobrze i przyświeca jej jeden wspólny cel - niepoli- } \\
\text { tyczny a gospodarczy, poprzez to realizowane są wszystkie } \\
\text { działania dzięki, którym wybudowano ogólnodostępny kom- } \\
\text { pleks sportowy typu Orlik, II miejsce w V edycji konkursu - } \\
\text { przeznaczenie 427.700 zł na remont Osiedlowej Przychodni dla } \\
\text { dorosłych, parking przy ulicy Srebrzyńskiej }\end{array}$ \\
\hline Radogoszcz & $\begin{array}{l}\text { zwycięstwo w IV edycji konkursu - pozyskanie 706.802 zł na } \\
\text { budowę ulic: Koniczynowej na odcinku od ul. Turzycowej do ul. } \\
\text { Szuwarowej oraz Turzycowej na odcinku od ul. Koniczynowej do } \\
\text { ul. Kruszynowej }\end{array}$ \\
\hline Stoki & $\begin{array}{l}\text { wszelkie udane inwestycje, budowa boiska sportowego przy ul. } \\
\text { Dębowskiego - Potokowej }\end{array}$ \\
\hline Śródmieście Wschód & $\begin{array}{l}\text { dotarcie do mieszkańców i zorganizowanie kilku imprez w } \\
\text { plenerze - rozpropagowanie funkcjonowania rady } \\
\text { zrealizowane inwestycje }\end{array}$ \\
\hline
\end{tabular}

Źródło: D. Weber, 2010.

Zdecydowana większość niepowodzeń działania rad osiedlowych wiąże się z barierami, które istnieją w Urzędzie Miasta i instytucjach mu podporządkowanych. Za podstawowe utrudnienia w swojej działalności przewodniczący badanych rad osiedlowych uznali: brak pieniędzy (8 rad), biurokracja ( 3 rady), brak osobowości prawnej (3 rady), małe kompetencje urzędników miejskich i opieszałość ich działań (3 rady) oraz inne przyczyny (2 rady).

Działania podejmowane przez wszystkie rady osiedli są podobne, ponieważ wynika to z zakresu ich kompetencji (patrz punkt 2). Zgłaszane natomiast przez poszczególne jednostki pomocnicze konieczność realizacji inwestycji dotyczy różnych potrzeb, co wiąże się z wielkością, specyfiką i stanem ich zagospodarowania. W badaniach z roku 2009 wśród zgłaszanych potrzeb podawane były najczęściej problemy związane z infrastrukturą techniczną (tab. 3.5).

Problemy te były również najważniejsze w badaniach 14 jednostek pomocniczych w roku 2013 (dla 9 jednostek). Należy jednak podkreślić, że pojawiły się do rozwiązania także, poza innymi sprawami technicznymi, takimi jak utrzymanie porządku i oznakowanie ulic (8 jednostek) oraz inwestycje dla instytucji publicznych (2 jednostki) - dotychczas słabo artykułowane, problemy społeczne, a mianowicie: łagodzenie konfliktów (8 jednostek) i bezpieczeństwo, w tym również drogowe ( 5 jednostek). 
Najważniejsze potrzeby zgłaszane przez rady osiedli

\begin{tabular}{|l|l|}
\hline \multicolumn{1}{|c|}{ Jednostka pomocnicza } & \multicolumn{1}{|c|}{ Zgłaszane potrzeby } \\
\hline Chojny - Dąbrowa & $\begin{array}{l}\text { odpowiednia - większa ilość środków finansowych w } \\
\text { stosunku do potrzeb (np. nowe chodniki i remont } \\
\text { istniejących, urządzenie placów zabaw) wpływ na trasy } \\
\text { komunikacyjne aby umożliwić ich funkcjonalność }\end{array}$ \\
\hline Im. Montwiłła Mireckiego & $\begin{array}{l}\text { oświetlenie placu między ulicami: Jarzynową i Barona } \\
\text { oraz kwestia jego zagospodarowania }\end{array}$ \\
\hline Radogoszcz & $\begin{array}{l}\text { Modernizacja starej części osiedla Radogoszcz Zachód } \\
\text { (kanalizacja, wodociągi, utwardzenie ulic) }\end{array}$ \\
\hline Stoki & $\begin{array}{l}\text { infrastruktura drogowa - asfalt, kanalizacja deszczowa na } \\
\text { znacznej części osiedla }\end{array}$ \\
\hline Śródmieście Wschód & rewitalizacja osiedla, budowa Nowego Centrum Łodzi \\
\hline
\end{tabular}

Źródło: D. Weber, 2010.

Podsumowując można stwierdzić, że działania rad osiedlowych przyczyniają się do zmian zachodzących w realnej przestrzeń miasta i przyczyniając się do lepszego zaspokajania potrzeb jego mieszkańców. Skala tych zmian jest jednak niewielka, co sprawia, że są one słabo uświadamiane przez mieszkańców poszczególnych jednostek pomocniczych.

\subsubsection{Społeczna ocena roli jednostek pomocniczych samorządu terytorialnego}

Rady osiedli, realizując rozmaite inwestycje, likwidują dysproporcje zagospodarowania wewnątrz i na zewnątrz jednostek osiedlowych, a także stymulują procesy integracji społecznej. Działania te mogą być jednak różnie oceniane przez społeczność lokalną lub wręcz niezauważalne. Przeprowadzone badania sondażowe miały na calu ukazanie, jak mieszkańcy postrzegają działalność Rad Osiedli i czy są one akceptowane.

Stopień informowania o działaniach rady mieszkańcy ocenili ogólnie źle (53\%). Tylko 9\% respondentów oceniło go dobrze, a 38\% średnio. Większość respondentów (62\%) nie wiedziała jakie inwestycje zostały zrealizowane w wyniku działań rady osiedla, a w związku z tym nie potrafiła określić swojego stosunku do tych działań (56\%). Z pracy rady zadowolonych było $19 \%$ respondentów wobec $24 \%$, mających o niej opinię negatywną.

W świadomości mieszkańców samorząd osiedlowy jest umiejscowiony słabo. Świadczą o tym następujące wyniki badań: ponad połowie respondentów (58\%) trudno było jednoznacznie określić, czy rady osiedla rozwiązują lokalne konflikty, czy też nie, a tylko 25\% sądziła (częściowo lub całkowicie), że rady spełniają tę funkcję, większość respondentów nie potrafiła określić, czy mieszkańcy mają wpływ na sprawy osiedlowe, czy też nie, wobec $38 \%$ uważających, że wpływ taki istnieje, prawie połowa badanych nie wie z kolei, czy samorząd osiedlowy przyczynia się do lep- 
szego zaspokajania potrzeb mieszkańców a druga połowa jest zdania przeciwnego. Respondenci są raczej przekonani, że wpływ mieszkańców na kierunki rozwoju osiedla nie może się ograniczać tylko do udziału w wyborach $(76 \%)$ a sprawy osiedlowe powinny być rozwiązywane przez obywateli (72\%) przy współudziale władz, natomiast tylko 7\% jest zdania przeciwnego. Można więc uznać, że mieszkańcy są przekonani o konieczności istnienia jakiejś formy organizacyjnej do rozwiązywania spraw lokalnych, w której zachodziłoby współdziałanie między władzą a mieszkańcami. Respondenci uznali zgodnie (87\%), że takim narzędziem wzmacniającym demokrację lokalną byłoby referendum. Silne przekonanie o roli referendum, może również świadczyć o ograniczonym zaufaniu mieszkańców do rad osiedlowych, co potwierdza zdanie większości (63\% respondentów), że radni nie powinni otrzymywać jakiegokolwiek wynagrodzenia za pracę wykonywaną społecznie (minimalną miesięczną dietę otrzymują tylko przewodniczący, jego zastępcy, sekretarz i skarbnik).

Niski poziom świadomości istnienia i funkcjonowania rad osiedlowych, ale także ich pozycja w strukturze władz Urzędu Miasta Łodzi, oraz zbyt duża wielkość jednostek pomocniczych mają wpływ na małe zaangażowanie i poziom gotowości mieszkańców do współdziałania. Pomimo ogólnie niskiego zainteresowania działaniami rady i bardzo ograniczonego zaangażowania społecznego mieszkańców, w mniejszych jednostkach istnieje większa wiedza respondentów na temat rady osiedla, jej członków, a także spraw i inwestycji, które udało się załatwić.

\subsection{Uwagi końcowe}

Po odrodzeniu samorządu terytorialnego, wraz z uchwaleniem Ustawy o Samorzqdzie terytorialnym w roku 1990, miał on być czynnikiem wyzwalającym kreatywność społeczeństwa i stymulować jego rozwój na różnych poziomach organizacji terytorialnej. Można było upatrywać w nim m.in.: ucieczki od centralizacji, odrodzenia społeczności i rynków lokalnych i oraz dostosowania warunków życia mieszkańców, wynikających z zagospodarowania przestrzeni, do ich potrzeb.

W artykule podjęto próbę wyjaśnienia roli i znaczenia rad osiedlowych, jako najniższej formy samorządności terytorialnej, w realizacji idei rozwoju i wyrównywania dysproporcji w przestrzeni realnej Łodzi (fizycznej i społeczno-przestrzennej). Działalność tych organów samorządowych, mimo bardzo silnego ich uwarunkowania zewnętrznego od władz gminy Miasta Łodzi, jest także zdeterminowana czynnikami wewnętrznymi (miejscowymi), co różnicuje kreowane przez rady osiedlowe zmiany przestrzenne i społeczne. 
Generalnie jednak myślenie o samorządzie terytorialnym dotyczyło poziomu gminy. Samorządność na poziomie osiedlowym nie była przedmiotem specjalnej troski czy zainteresowania przez władze centralne, regionalne, a tym bardziej gminne. Ustawa dopuszczała tworzenie jednostek pomocniczych gmin, co miało pomagać w zarządzaniu przestrzenią miasta, stanowić pewien rodzaj zaplecza informacyjnego oraz kadrowego dla władz gminy, aktywizować i integrować społeczności osiedlowe, ogólnie być jednym $\mathrm{z}$ lokalnych narzędzi budowania w Polsce społeczeństwa obywatelskiego.

Rady osiedli są powoływane do reprezentowania mieszkańców. Wspomniana ustawa dość ogólnie określiła funkcje i sposób tworzenia rad osiedlowych. W Statucie Miasta Łodzi oraz statutach poszczególnych jednostek pomocniczych wyznaczono im zadania do zrealizowania, określono kompetencje i granice odpowiedzialności, zasady finansowania i pozyskiwania dodatkowych funduszy. Jednostki pomocnicze nie mają zagwarantowanej samodzielności ani osobowości prawnej, a ich celem jest realizowanie polityki miasta.

Należy podkreślić, że stworzone ramy prawne dla samorządu osiedlowego i działanie instytucji osiedlowych są ważnymi determinantami funkcjonowania samorządności osiedlowej. Przepisy prawa nie rozstrzygają jednak o efektywności działań jednostek pomocniczych, która zależy od stosunku władz miejskich do samorządu pomocniczego oraz od samych mieszkańców osiedli.

Łódź jest zbiorem wielu jednostek osadniczych o różnorodnej genezie, odmiennym rozwoju historycznym tudzież o znacznych odrębnościach funkcjonalnych i zróżnicowanych cechach urbanistycznych i architektonicznych. Zamieszkująca je ludność tworzy pewne społeczności lokalne, niekiedy zintegrowane o znacznym poczuciu odrębności. Jest to niewątpliwe rezultat odmiennych losów poszczególnych części miasta w procesie rozwoju historycznego jak też odmienności struktur społecznych ich ludności.

Członkowie rad stanowią najważniejszy element całości systemu jednostek pomocniczych miasta. Bez ich zaangażowania, aktywności społecznej i woli działania na rzecz wspólnego dobra, badane rady nie miałyby podstaw do powstania. Motywami, jakie skłoniły ich do pracy w radach, były m.in. wspólny interes dotyczący najbliższego otoczenia, pomoc innym i sobie, wcześniejsza aktywność w różnych grupach i organizacjach oraz wspomniane już zasoby wolnego czasu. Najbardziej nawet zaangażowani społecznicy zrezygnują jednak z pracy na rzecz samorządu pomocniczego, jeśli miasto nie stara się stworzyć im odpowiednich warunków organizacyjnych i finansowych do działania oraz jeśli nie będą traktowani z odpowiednim szacunkiem i powagą. Rady osiedlowe gromadzą wielu lokalnych aktywistów, których wysiłek i zaangażowanie warte są podkreślenia. 
Rada osiedla dysponuje środkami finansowymi przekazywanymi przez UM na realizacje w trybie tzw. algorytmu zadań inwestycyjnych i remontowych, a także nowych inwestycji wyłanianych w ramach corocznie przeprowadzanego konkursu. Kolejnymi źródłami dochodów są darowizny, spadki i zapisy przekazane na rzecz miasta, jednak z przeznaczeniem dla osiedla oraz dochody z mienia komunalnego, które miasto przekazało osiedlu.

Badania pokazały, że główny zakres realizowanych zadań dotyczy infrastruktury, gospodarki komunalnej, oświaty i wychowania. Okazało się, że wykonywane inwestycje są praktycznie takie same - skupione w dużej mierze na infrastrukturze, różnice mogą się pojawiać jedynie w odniesieniu do ich skali i przeznaczanych środków finansowych. Najczęściej inwestycje dotyczą budowy nowych chodników i dróg oraz modernizacji tych już istniejących, placów zabaw dla dzieci, wyposażania ich w niezbędny sprzęt, jak również urządzania boisk sportowych.

Poza działaniami na rzecz zmian w zagospodarowaniu przestrzennym, rady osiedlowe podejmują działania rozwijające więzi społeczne między mieszkańcami osiedla, co jest niezbędnym warunkiem powstawania wspólnot terytorialnych. Głównym narzędziem kształtowania tych więzi są organizowanie dla mieszkańców osiedla różne spotkania, takie jak festyny, kolacje wigilijne, śniadania wielkanocne itp., a także konkursy i turnieje sportowe.

Badane rady odnosiły różne sukcesy, ale ponosiły także pewne porażki. Podkreślenia wymaga fakt, że zakres zadań rady osiedla jest dość szeroki, jednak faktyczny wpływ na zaspokajanie potrzeb wspólnoty samorządowej jest marginalny. Realnie widać, że rady mają niewielkie znaczenie w rozwoju zagospodarowania i w niwelowaniu dysproporcji przestrzennych oraz społecznych. Podstawowa tego przyczyną jest niski poziom umocowania prawnego, a co za tym idzie i kompetencyjnego, oraz stosunkowo niewielki budżet, co w sumie sprawia, że jednostki pomocnicze są generalnie ignorowane zarówno przez władze gminy, jak i samych mieszkańców.

Samorządność jest zachowaniem aktywnej postawy cywilno- obywatelskiej, w celu ulepszenia i usprawnienia najbliższej rzeczywistości społecznej i publicznej. Siłą jednostek pomocniczych powinna być zatem ich lokalność, gdyż jest to najbliższy mieszkańcom szczebel samorządnej władzy. Badania dowodzą, że w przypadku Łodzi jest to tylko siła teoretyczna. Dzieje się tak również dlatego, że kwestia samorządności osiedlowej była i jest mało znana mieszkańcom. Większość respondentów odpowiadała na pytania o rzeczywistość, o której mieli małe pojęcie, a samorządy osiedlowe były znane tylko nielicznym zainteresowanym. Zróżnicowanie tej wiedzy jest m.in. zależne od wielkości osiedli. W małych jednost- 
kach wiedza na temat rad osiedlowych była dość duża, w tych zaś wielkopowierzchniowych i gęsto zaludnionych - bardzo mała i ogólnikowa bądź nawet żadna.

Świadomość mieszkańców, w zakresie istnienia samorządu pomocniczego, jego kompetencji i możliwości działania, a także jego roli pośrednika między nimi a Urzędem Miasta Łodzi, jest ogólnie bardzo niska, co z kolei warunkuje aktywność wyborczą, a następnie chęć uczestniczenia w pracach rad osiedli, czy start w wyborach do władz jednostki pomocniczej. Porównanie dwóch ostatnich wyborów do rad osiedlowych w odniesieniu do frekwencji wyborczej, liczby zgłoszonych list wyborczych i liczby kandydatów na radnych wskazuje na pogłębiający się jeszcze proces dezaktywności społecznej mieszkańców jednostek pomocniczych w Łodzi. Badania przeprowadzone wśród mieszkańców wybranych osiedli pokazały ich nikły stopień zainteresowania radami osiedli, bardzo małą wiedzę na temat ich działalności oraz niski poziom zaangażowania społecznego. Im bardziej mieszkańcy identyfikowali się ze swoim osiedlem, tym większą wykazywali aktywność lokalną i zainteresowanie najbliższym otoczeniem. Okazało się, że mikrospołeczne procesy związane z lokalnym zaangażowaniem są złożone (Matczak 2008). Dostrzegalne jest istnienie „błędnego koła", w którym niska świadomość społeczna, dotycząca lokalnej samorządności terytorialnej (funkcji i możliwości działania rad osiedlowych), skutkuje niską aktywnością mieszkańców, co osłabia działanie samorządu, natomiast słabo działający samorząd negatywnie nastawia do siebie mieszkańców pogłębiając ich społeczną bierność i przekonanie o bezsensowności działań na rzecz dobra wspólnoty terytorialnej. Ponadto działanie rad osiedli i spółdzielni mieszkaniowych na terenie Łodzi skutkuje w ocenie mieszkańców niejasnością ról poszczególnych jednostek administracji.

Rady osiedli (jednostki pomocnicze gmin) to termin określający odrębność administracyjną, bez względu na inne cechy charakterystyczne: poczucie odrębności mieszkańców, specyfikę ze względu na układ osadniczy i przestrzenny, odrębność społeczną, gospodarczą itd. Oczywiste jest jednak, że $\mathrm{w}$ wielu przypadkach poszczególne wymiary nakładają się na siebie. $\mathrm{W}$ istocie rady osiedli usytuowane są $\mathrm{w}$ przestrzeni między sferą struktur władzy formalnej a sferą nieformalnej samoorganizacji społecznej.

Wybór rozwiązań konstytucyjnych szczegółowych, dotyczących jednostek pomocniczych gmin, był pochodną przekonania, że decentralizacja i demokratyzacja są korzystne dla obywateli. Rady osiedli miały być zatem instrumentem budowy społeczeństwa obywatelskiego. Badania ukazały jednak niewielkie możliwości tych rad w zakresie przeprowadzania zmian i wyrównywania dysproporcji przestrzennych oraz kreowania więzi spo- 
łecznych, co potwierdzają badania prowadzone w Poznaniu i Kaliszu przez P. Matczaka (2008). Główne przyczyny tego stanu są następujące:

- słabe umocowanie i kompetencje prawno-finansowe samorządu pomocniczego w strukturze organizacyjnej miasta tudzież wynikające $\mathrm{z}$ tego ubezwłasnowolnienie organów administracyjnych jednostek pomocniczych,

- struktura funkcjonalno-przestrzenna i społeczno-przestrzenna jednostek pomocniczych, które są heterogeniczne i w związku z tym nie ma możliwości godzenia interesów wszystkich mieszkańców silnie różniących się społecznie i zamieszkujących w bardzo różnych obszarach,

- niechętny stosunek władz miasta do działalności rad osiedlowych i taktowanie ich jako zła koniecznego, które trzeba tolerować ze względów pijarowych - są argumentem za funkcjonowaniem społeczeństwa obywatelskiego, co skutkuje dość lekceważącym stosunkiem władz miasta do rad osiedlowych,

- przekonanie mieszkańców o niskiej skuteczność działania, wynikające z: braku świadomości istnienia rad, wiedzy o sprawach załatwianych braku informacji i komunikacji rad z mieszkańcami oraz utrwalonego poglądu, że radni pochodzą z układów nomenklaturowych i dbają głównie o sprawy, którymi są sami zainteresowani, a nie o sprawy dotyczące całej jednostki terytorialnej.

\section{LITERATURA}

Barański M., Kantyka S., Kubas S., Kuś M., 2007, Samorzq̨d terytorialny i wspólnoty lokalne, Wydawnictwo Wyższej Szkoły Pedagogicznej TWP, Warszawa.

Buksiński T., Bondyra K., Jakubowski J., (red.), 2007, Demokracja - samorzq̨dność prawo, Wydawnictwo Naukowe Instytutu Filozofii, Poznań.

Chojnicki Z., 1999, Podstawowe problemy filozoficzne i metodologiczne przestrzeni i czasu, [w] Podstawy metodologiczne i teoretyczne geografii, Bogucki Wyd. Naukowe, Poznań

Dz Urz Woj Łódzkiego, nr 23, poz. 148, Statut Miasta Łodzi z dnia 23 listopada 2005 r., www.dziennik.lodzkie.eu.

DzU, 1990, nr 16, poz. 95, (Ustawa z dnia 8 marca 1990 r. o samorządzie gminnym), www.isap.sejm.gov.pl.

Gąciarz B., 2004, Instytucjonalizacja samorzq̨dności, Wydawnictwo IFiS PAN, Warszawa.

Konstytucja Rzeczypospolitej Polskiej z dnia 2 kwietnia 1997 r.

Koter M., Araszkiewicz A., Kunka T., Łukowska A., 1991, Koncepcja podziału m. Łodzi na jednostki pomocnicze, Kronika Miasta Łodzi. 
Lisiński M., (red.), 2007, Słownik podstawowych terminów samorządu terytorialnego, Wyższa Szkoła Biznesu w Dąbrowie Górniczej, Dąbrowa Górnicza.

Lisowski A., 2003, Koncepcje przestrzeni w geografii człowieka, Wydział Geografii i Studiów Regionalnych UW, Warszawa.

Matczak P., 2008, Rady osiedli: w poszukiwaniu sensu lokalnego działania, Wydawnictwo Naukowe Uniwersytetu im. Adama Mickiewicza, Poznań.

Pająk K., 2003, Samorzad terytorialny w Polsce Wybrane aspekty jego funkcjonowania, Wydawnictwo Akademii Bydgoskiej im. Kazimierza Wielkiego, Bydgoszcz.

Turowski J., 1979, Środowisko mieszkalne w świadomości ludności miejskiej, Ossolineum, Wrocław.

Weber D., 2010, Rady osiedlowe jako forma społecznej samorzadności mieszkańców Łodzi, maszynopis pracy magisterskiej, promotor: prof. dr. hab. A. Suliborski, Katedra Geografii Regionalnej i Społecznej UŁ, Łódź.

Zubik A., Cieślik A., 2007, Prawdy i mity na temat nierówności społecznych, [w:] J. Klebaniuk, (red.), Fenomen nierówności społecznych. Nierówności społeczne $w$ refleksji humanistycznej, ENETEIA, Wydawnictwo Psychologii i Kultury, Warszawa.

Uchwały Rady Miejskiej Miasta Łodzi (www.bip.uml.lodz.pl):

Uchwała nr LV/1052/05 Rady Miejskiej w Łodzi z dnia 12 października 2005 r.

Uchwała nr XIII/143/91 Rady Miejskiej w Łodzi z dnia 20 marca $1991 \mathrm{r}$.

Uchwała nr XIX/210/95 Rady Miejskiej w Łodzi z dnia 4 października 1995 r.

Uchwała nr XXXIV/754/2000 Rady Miejskiej w Łodzi z dnia 5 kwietnia $2000 \mathrm{r}$.

Uchwała nr XXXIV/755/2000 Rady Miejskiej w Łodzi z dnia 5 kwietnia 2000 r.

Zarządzenie nr 2952/V/09 Prezydenta Miasta Łodzi z dnia 26 marca 2009 r.

Strony internetowe:

www.bip.uml.lodz.pl

www.halolodz.pl

www.uml.lodz.pl

www.isap.sejm.gov.pl

www.dziennik.lodzkie.eu 